\title{
The Impact of Irrigation Participation on Labor Time Female Allocate to Farm Activities in Ethiopia (WEST SHEWA ZONE :In Case of Bako Tibe Woreda)
}

\author{
Tasfaye Fikadu Fayisa ${ }^{1,2}$ \\ 1.Economics Department, Wollega University, PO Box 395, Nekemte, Ethiopia \\ 2.Economic Analyst, Gada Consulting PLC, Nekemte, Ethiopia
}

\begin{abstract}
This study wants to analyze the impact of irrigation on time females spend on farm activities using Augmented Inverse probability weight model of treatment effect based up on data obtained from sampled population of randomly selected Dembi Dima and Dembi Gobu kebeles of Bako Tibe Woreda. The resulted show that the average times those females spend on farm activities per week is 39.11 hours if none of sample size was irrigators. The average time if all females to irrigate is 20.54 hours per week more than this amount. Since the study showed that irrigation has impact on increasing the time females spend NGOs and government shall work in way more females could be included in irrigation by working on issues of accessing land to river and making adjustment of unutilized land and extension service for irrigation purpose
\end{abstract}

Keywords: Irrigation, Augmented Inverse probability weight, Female, Ethiopia.

DOI: $10.7176 /$ EJBM/13-17-01

Publication date:September $30^{\text {th }} 2021$

\section{Introduction}

The female-to-male ratio of labor force participation rates is the ratio of labor force participation rate among women to the corresponding rate for men (ILO, 2018). Female and the same is true for male in fact, in labor force participation can be examined by looking at the factors affecting labor demand and supply. Labor demand is mainly determined by the increase in production, the development of part-time and public sector employment. Whereas the factors affecting labor supply are measured as the increase in female educational achievement, deferment of fertility and the change in the approach of female employment. Also economic, cultural and sociological issues are the factors affecting female labor force participation (Tasseven et al, 2016).

Small scale irrigation is an essential scheme in reducing risks associated with rainfall variability and increasing income of rural farm (Abraham et al, 2015; Tsegazeab and Surajit, 2016). It also supplements farm income and serve as diversification instrument. However, though whether it adverse the usual male labor force participation dominance or not are not yet studied thoroughly, whether it increases female labor force participation among themselves is not studied too. Studies undertaken in Ethiopia are confined to determinants of irrigation participation, the impact of irrigation on women diet ( Kaleab et al ,2019), the impact of irrigation on income and livelihood ( Chilot, 2012; Tsegazeab and Surajit, 2016 ).

While the gap between female and men labor force participation changes from time to time and hence well studied (Abraham et al, 2015 ; Tsegazeab and Surajit, 2016, Chilot, 2012; FAO,2019) the gap among female themselves regarding irrigation decision participation and the time spend is not studied well. Though, the gap among female themselves could attribute to factors aforementioned. This study wants to see the impact of irrigation on female labor time allocation on farm activities. That is, this study wants to carry out research on whether females engaged on irrigation have more labor time allocation on farm activities or not compared to not irrigated using instrumental method of treatment effect model using primary data going to be collected from sampled female in west Shewa Zone, Bako Tibe Woreda.

\section{$2 \quad$ Literature}

Ethiopia has 12 river basins. The total mean annual flow from all the 12 river basins is estimated at about 122 BMC (MoA, 2011a). However, Ethiopia remains mainly dependent on rain fed agriculture. The country accepts substantial rainfall, although supply and strength varies, generally decreasing from southwest to northeast. Droughts occur every four or five years. If well managed, Ethiopia's surface water and groundwater systems are sufficient to meet most domestic and irrigation purposes. But the lack of installed water infrastructure provides a serious constraint to irrigation development (FAO, 2015). Another problem is, despite its vast potential, Ethiopia still has a relatively undeveloped market for irrigation equipment. Distributors are concentrated in Addis Ababa. These distributors supply irrigation equipment in other areas of the country, but they tend to operate from their headquarters in the capital. The same study stresses that the most barrier to small scale irrigation is access to credit. For small-scale farmers living under the poverty line, it is hard to afford even the cheapest irrigation pumps. A number of NGOs and MFIs work with small-scale farmers to help them secure financing for irrigation pumps and 
equipment, but even these have limited capacity (MoWR, 2002). River diversion, small earth dams, pump irrigation system with ground water are some of irrigation systems most commonly found in Ethiopia. But, the most commonly used irrigation technique in Ethiopia is surface irrigation. Of these, surface irrigation constitutes around 98 percent. Sprinkler irrigation accounted for approximately 2 percent. Localized irrigation was negligible (FAO , 2015; MoWR, 2002)

In Ethiopia, different literatures reports differently regarding the amount irrigation water resources as irrigation potentials, area irrigated right now. For example FAO estimates that Ethiopia's potential irrigable land amounts to 2.7 million hectares of which only 11 percent of this area was equipped for irrigation in 2001, which was among the lowest percentages in Africa. Since then the International Water Management Institute reports the area to have grown to 610000 hectares in 2010. Similarly, from farm size per household 0.5 ha to 2 ha, the irrigated land per households' ranges from 0.25 - 0.5 ha (FAO,2015).

According to Ministry of Water Resources of Ethiopia (MoWR, 2002), irrigation development in Ethiopia is classified based on the size of the command area, in three types:

1. Small-scale irrigation systems $(<200$ hectares ha)

2. Medium-scale irrigation systems (200-3,000 ha)

3. Large-scale irrigation systems $(>3,000 \mathrm{ha})$

This classification system is the most common in Ethiopia. Accordingly, $46 \%$ of proposed irrigation developments are in the small-scale irrigation category (Makombe et al, 2011). The intended research will focus only the first kind of irrigation since the last two are large and virtually owned by government.

According to the 2007 Population and Housing Census, the term economic activity status refers to the size and distribution of the work force of economically active and non active population. Persons aged ten years and over who were engaged or available to be engaged in the production of economic goods and services during a given reference period were classified as economically active, while those who were neither engaged nor available to be engaged in the production of economic goods and services during a given reference period were considered as economically non-active (CSA, 2013).

According to labor-leisure optimization theory, labor participation rate is considered together with expected market wage and the value women give to the time they spend for housework. Neoclassical theory states that labor supply is the choice between work and leisure and is an increasing function of real wage for individuals. Labor demand is a decreasing function of real wage. Neoclassical theory is based on the assumption of free market competition.

On the other hand, labor seeking theory states that neither employees nor firms have full information about labor market. Labor seeking theory has the alternative cost of sacrificing free time as well as getting information. It accepts the existence of unemployed individuals and empty job positions which corresponds to these individuals. In the literature female labor force participation in developing countries is affected by (World Bank, 2011, ILO, 2018, Gronau ,1973)

\subsection{Determinants of labor time allocation}

According to the 2007 Population and Housing Census, the term economic activity status refers to the size and distribution of the work force of economically active and non active population. Persons aged ten years and over who were engaged or available to be engaged in the production of economic goods and services during a given reference period were classified as economically active, while those who were neither engaged nor available to be engaged in the production of economic goods and services during a given reference period were considered as economically non-active (CSA, 2013).

According to labor-leisure optimization theory, labor participation rate is considered together with expected market wage and the value women give to the time they spend for housework. Neoclassical theory states that labor supply is the choice between work and leisure and is an increasing function of real wage for individuals. Labor demand is a decreasing function of real wage. Neoclassical theory is based on the assumption of free market competition.

On the other hand, labor seeking theory states that neither employees nor firms have full information about labor market. Labor seeking theory has the alternative cost of sacrificing free time as well as getting information. It accepts the existence of unemployed individuals and empty job positions which corresponds to these individuals. In the literature female labor force participation in developing countries is affected by (World Bank, 2011, ILO, 2018, Gronau ,1973)

1. Level of economic development.

2. Educational attainment.

3. Access to credit and other inputs.

4. Household and spouse characteristics.

5. Institutional setting (laws, protection, benefits).

6. Social dimensions, such as social norms influencing marriage, fertility, and women's role outside the 


\section{household.}

\subsubsection{Female labor time allocation and household characteristics}

I. Female labor time allocation and Economic development

Though the relationship between female labor force participation and income can be studied one by one the widely investigated is the relationship between female labor force participation and economic development, virtually taken as U shape.

The basic, stylized argument of $U$ shape is that when a country is poor, women work out of necessity, mainly in subsistence agriculture or home-based production. As a country develops, economic activity shifts from agriculture to industry, which benefits men more than woman (Goldin, 1995). Subsequently, education levels rise, fertility rates fall, and social stigmas weaken, enabling women to take advantage of new jobs emerging in the service sector that are more family-friendly and accessible. At a household level, these structural shifts can be described in the context of the neoclassical labor supply model: as a spouse's wage rises, there is a negative income effect on the supply of women's labor. Once wages for women start to rise, however, the substitution effect will induce women to increase their labor supply.

Essentially, the $U$ shape hypothesis proposes that female participation rates are both the cause and consequences of economic development. As more women enter the labor force, economies can grow faster in response to higher labor inputs. At the same time, as countries develop, women's capabilities typically improve, while social constraints weaken, enabling women to engage in work outside the home (MacDonald and Petersen, 2018).

Hence, female labor force participation are highest in poor countries, where women are engaged in subsistence activities, and fall in middle-income countries because of the transition of (mainly) men to industrial jobs. As education levels improve and fertility rates fall, women are able to join the labor force in response to growing demand in the services sector.

However, there has been debate on the validity of this hypothesis, particularly on its robustness to different data sets and methodologies. One study finds that the U-shaped relationship is not robust once dynamic generalized method of moments (GMM) panel data techniques are employed (Gaddis et al, 2015).

Though the U shape relationship between income and female labor time allocation is at macro level, income of household and/or nonfarm activities at micro level also basically affects female labor time allocation on farm activities though the direction of change will depend on sources of income. For example income of household can enable households to have capacity to buy inputs and accessible to information (FAO, 2019) whereas income from non-farm activities would have a negative relationship with probability of participation ( Chilot, 2016). This is because Household head that earns off-farm income may have little time to participate in farming activities in small holder irrigation schemes.

Another determinant of female labor force participation is sex. In most literature men are more likely to participate in the labor force than women (ILO, 2018). They claim that traditionally men's work is on productive, marketable and outdoor job.

2.1.2 Female labor time allocation and female characteristics

i) Female labor time allocation and Educational attainment.

One of the strongest determinants of labor market outcomes in both developed and developing countries is educational attainment. From a supply-side perspective, education has an important impact on an individual's decision to participate in the labor force (Cazes et al, 2013).

According to ILO (2018), People with more education are more likely to participate in the labor force than people with less education. The difference in labor force participation due to education is higher for female than men. For example in 2017, the participation rate of men ages 25 to 54 with at least a college degree in US was 9 percentage points higher than the rate for men without a college degree. For women, the difference was 13 percentage points. For both sexes, the growth of female labor force participation between educated and uneducated is more female than men (Congress of the United States, Congressional Budget Office, 2018). For OCED countries the difference in labor force participation between people with more education and people with less education has grown. Between 1990 and 2017, the share of men with at least a college degree increased from 27 percent to 33 percent and the share of women with at least a college degree climbed from 23 percent to 38 percent (Tasseven et al, 2016).

Gronau (1973) also found that education played an important role in determining the market wage, but concluded that the rate of return on education was underestimated due to a negative correlation between education and true residuals in the wage equation.

ii) Female labor time allocation and marital status.

Married men are more likely to participate in the labor force than men who are not married, whereas married women are less likely to participate than their unmarried counterparts. Presence of young children also affects women labor force participation. Having children under the age of 5 at home is related to the labor force participation of women but not men and varies with marital status. Married women with young children are less 
likely to work than married women without young children, whereas unmarried women with young children are more likely to work. The above stated some of those demographic factors are influenced by policies though it has very little applicability for rural areas.

2.1.3 Female labor time allocation and Institutional setting (laws, protection, accessibility and Norms)

I. Norms and culture

Social norms and culture circumscribe the extent to which it is possible or desirable for women to enter the labor force. Socially assigned gender roles have often been institutionally enforced. And this is still the case today (Alesina, Giuliano and Nunn 2013). In most countries around the world, especially in developing country, there are restrictions on the types of work that women can do, virtually restricted to home.

In rural areas, in most parts of the country, women are deeply involved in most aspects of agricultural production, marketing, food procurement and household nutrition; however there is a view widely held that "women do not farm". This cultural perception remains strong even though numerous agricultural tasks are regarded as women's work, including weeding, harvesting, preparing storage containers, managing all aspects of home gardens and poultry, transporting farm inputs to the field and procuring water for household and some onfarm use. Women often dominate in the cultivation of horticulture, especially vegetable crops. Such crops are commonly grown on small plots in the vicinity of the house, or in the compound (Mogues et al. 2009)

In spite of social norms being persistent, there is also proof that large changes are possible. Research in this area shows that social norms and culture can be influenced in a number of non-institutional ways, including through intergenerational learning processes, exposure to alternative norms, and activism which propelled the women's movement (Fernandez, R. 2013) which would probably be confined to urban areas.

II. Accessibility.

The EPDRF of Ethiopia implemented its ADLI policy in 1993. In the framework of this strategy, the government initiated in the early 1990s a big drive to disseminate agricultural packages to farmers, which included fertilizer, improved seeds, credit, and the provision of extension services. The main government institutions responsible for planning and implementing agricultural policies and projects are

There is also difference between females and males on advisory receiving from agricultural extension for example, according to An agriculture sample survey conducted by CSA in 2013 showed that more than half of sample crop growers reported that they received crop production related advisory services. However, the percentage share of female holders who received such advisory services was about 13 percent lower than that of male holders who received these services (CSA, 2013). Access to credit is also one of the biggest barriers to the irrigation sector's expansion in Ethiopia. For small-scale farmers, finance is not readily available, and some struggle to afford even the cheapest irrigation equipment. A number of NGOs and MFIs work with small-scale farmers to help them secure financing for irrigation pumps and equipment, but their financial capacity is also limited (MoWR, 2002)

The institutions that are supposed to provide financial services in rural areas are Micro Financial Institutions (MFIs) and rural saving and credit associations (RSACCOs). Other financial institutions like commercial banks are not accessible for most rural men and women. The Microfinance Proclamation 40/1996 added the possibility for MFIs to provide deposit-taking services. Despite these efforts in March 2015, there were only 24 MFIs providing financial services in rural areas. Their penetration ratio is still low, with less than 4 percent of the national population being served (FAO,2019)

Accessibility to information is another determinates affecting labor time allocation. The sources of information are different for male and female. A sample survey by Aregue et al (2010) found that the sources of agricultural and non-agricultural information generally depend on gender differences. Men depend mainly on formal information sources while women mostly exploit informal sources of information. In addition to gender differences, wealth status also influences the kind of knowledge and sources of skill for farmers

Another important accessibility problem is technology. Some of the indicators of modern technology application are improved seeds, fertilizers, agricultural chemicals (such as herbicides, pesticides, etc.). In almost all the indicators of technology and input use, female heads are less likely to use or adopt improved technologies and use less input. Plots of male heads are more likely to be applied with chemical fertilizer, improved seeds and herbicides, while plots of female heads are more likely to be applied with manure and limited improved seeds (CSA, 2013).

In this way, Only 2 percent of agricultural land is irrigated and applied with pesticide, with plots of male heads more likely to be irrigated and applied with pesticide (EDRI \& IFRI, 2012). Irrigation technologies are supply driven and technically focused. Little technical consultation is done by farmers who rely on indigenous knowledge instead, and therefore have limited access to innovations.

\subsection{Empirical Literature}

Chilot Yirga adopted two -stage Heckman model to analyze determinants of female participation on irrigation and ordinary least square to see its effect on income. According to the study, income, gender, access to market 
information and health condition of households are profound determining factor for participating in small scale irrigation schemes. The investigation added that irrigation participation, family labor force, livestock ownership and access to market information and credit are positively and significantly associated with household income. The study did not include the effect of irrigation on labor force participation.

Tsegazeab and Surajit (2016) used propensity score matching to see the impact of small scale irrigation on household income in Bambasi Woreda, Benishangul-Gumuz region, Ethiopia. The assessments of the propensity score matching of the probit model shows that gender, the linear and non-linear age, education, plot size, social position participation, extension service, access to credit and total livestock unit are the statistically significant factors that significantly affects the income of small scale irrigation

Generally, the is no study on the impact of irrigation on female labor force participation in Ethiopia using any kinds of model. As discussed above, almost all are confined to determinants of participation using binary dependent variable and others are on income. This study will use the time females spend on activities outside home. For irrigated females are going to be asked how much they spend on irrigation and others whereas for non- irrigated are going to be asked how much they spend on agriculture but non irrigation. This data will be used as dependent variable. The different is going to be seen using propensity score matching.

2.2.1. Conceptual framework

Many studies ( for example Bunclark, 2010) have found that the major determinants of female's labor time allocation in small holder irrigation schemes are mainly due to socioeconomic dimensions of households, the institutional and technical factors

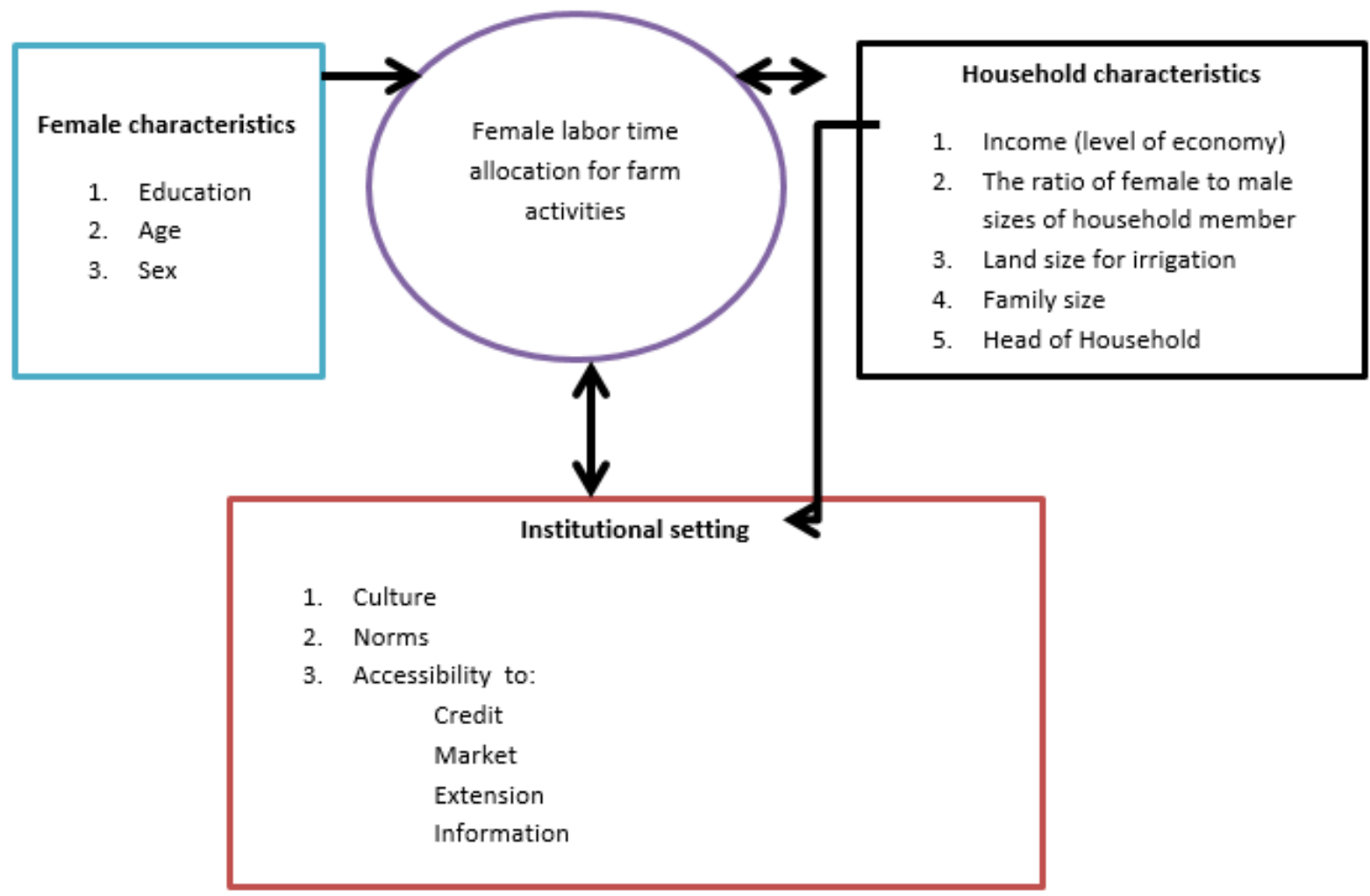

Source: own development from literature

Figure1: Conceptual framework

Conceptual framework in figure 1 above shows that factors affecting female labor time allocation are female characteristics, household characteristics and institutional set up. Income of household the ratio of female to male in the household, land size, head of house hold and family size can affect labor time allocation from the view of household characteristics. Culture, norms and accessibilities in terms of market, information, extension service, credit and technology are issues related to institutional set up. Peculiarities related to female like age, education whether head or not can affect also female labor time allocation on farm activities.

The way how family size and land size affect labor time allocation is straightforward. The higher land size the higher irrigation. The higher family sizes the higher labor time allocation of female on farm activities because larger family size needs high demand for food and expenditures. However, since the study is on female labor time allocation on farm activities, composition of female-male also matter. The lower female to male ratio the more labor time a given household needs female time at home for food preparation and vice versa. Income affects labor time allocation of female farm activities. The higher income the capacity of farm to buy inputs and hence higher 
time allocation. It also affects accessibility to information and market. But, this would be applicable largely for medium scale irrigation. Most small scale irrigation is on pieces of land and just to improve income of household. Thus, labor time allocation affects also income of household. Female labor time allocation on irrigation also depends up on whether female is head or not. For instance, the study by Chilot (2011) shows those male headed households are $38 \%$ more likely to participate in irrigation practices than female headed households. This is because the latter suffer from lower income, poor financial asset and faced a shortage of labor and market information. Thus, women in female headed households frequently ended up renting or sharing out their land

\section{Research design}

The proposed study employed cross-sectional research design because it is better and more effective for obtaining information about the current status or the immediate past of the case under the study. It is also appropriate and suitable to use data collection tools such as questionnaires, interviews, focus group discussion, field observation and document analysis. Since the study wants to answer whether irrigation increases the amount time female spend on farm activities or not quantitative data analysis was used. Moreover, as was discussed under sampling method, mix of random and purposive ways of sampling method were used and hence quasi-experimental design.

\subsection{Description of the Study Area}

Bako Tibe District is found in Western Shewa Administrative Zone, Oromia Regional State, about $250 \mathrm{~km}$ west of Finfinne ; $125 \mathrm{~km}$ from Ambo, zonal capital city and $81 \mathrm{~km}$ east of Nekemte city at latitude of $9.12^{0} \&$ longitude of $37.05^{\circ}$. The district borders, East Wollega in the south and West, Horro Guduru Wollega in North, Chaliya and Illu/Galan District in the East (ARDO, 2018)

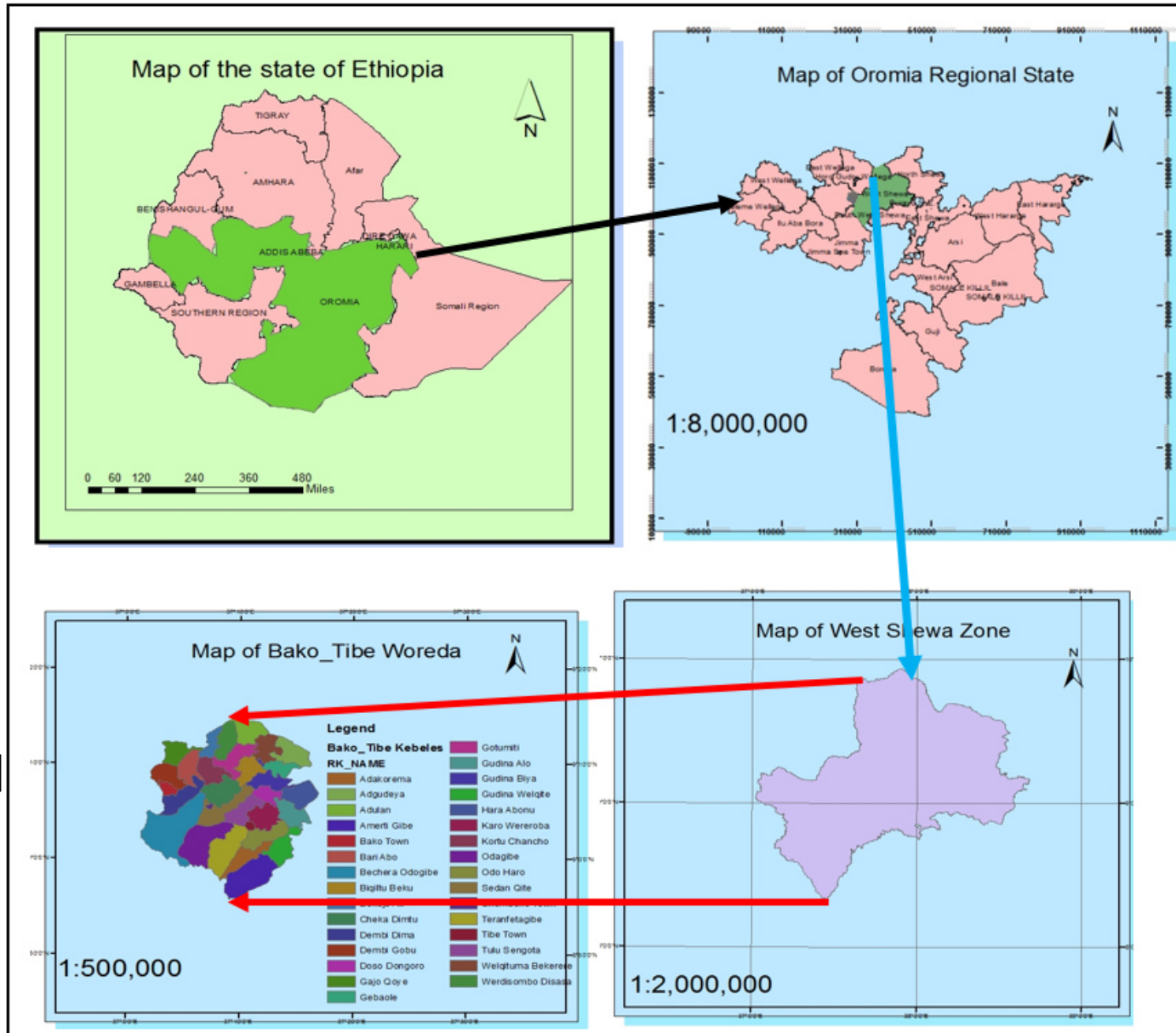

Figure 2: Map of the study area

From the outset Bako Tibe Woreda was purposefully be selected because the area is known for irrigation. Irrigation users are female households, who head it or serve as member, who own land, rented/shared or gifted in land for direct utilization, where as non-users is composed of households who neither owned irrigated land nor involved in irrigation farming. 


\subsection{Sampling Technique and sample Size}

The study is aimed at looking whether irrigation creates difference among females on irrigation and not. Hence, the study has taken Sample from female member farm household's small-scale irrigation users and non-users in Bako Tibe woreda (study area). To arrive at representative sample, two stage probability sampling technique were employed next to the first non-probability district selection. The district has 32 kebeles administrative units, for which four(4) kebeles are under urban administration while the remaining twenty eight (28) kebeles are under rural administrative. Ecologically, Out of these rural kebeles, fifteen $(53.5 \%)$ kebeles are found in lowland agro ecologies while that of midland is ten $(35.7 \%)$ kebeles and three $(10.8 \%)$ are in the highland kebeles are found in the highland agro ecology (ARDO, 2018). Hence, these ecology are going to be the base for stratification. However, irrigation is practiced in low lands mainly and midland and no irrigation at all at highlands. Accordingly, only low lands and midlands were sources of respondents.

To decide whether both ecological zones are going to be used or not two issues should be focused here. The first one is about treatment model. Except in variable under focus (irrigation here) treatment and control group must be homogeneous -if not the result will be misleading (wooldridge, 2002, veerbeck,2004). This is because if that is not the case, the difference in outcome would be not necessarily as a result of the variable under focus. In this way we have to confine to either ecological zone if there is evidence that there is heterogeneity across ecological zone which is automatic- if not why strata come first? The second one is the issues of representativeness which implies the use of both ecological zone and contradicts to the first issue. According to Kothari (1990) the claim that both strata should be included is when one is aimed at comparison between the strata which is not the case in this study. Hence, using simple random sampling low land was selected.

Now, low land has 15 kebeles. Since all are almost similar, two kebeles are selected randomly: Dambi Dima and dambi Gobu kebeles. Both together have 7511 total population, 3735 male and 3775 female and 1553 households (CSA,2007). Of these households 310 households engaged in irrigation while the remaining 1243 are not. According to Ajay and Micah (2014) there are four ways of calculating proportional sample size: Cochran (1963, 1975), Yemane (1967) and Rao (1985) while Cochran sample is applicable for large population, Rao is for field survey to estimate the prevalence rate of specific event or cases or disease. In this case only Yemane (1967) will be used.

The following table summarizes how total sample size determined using Yemane (1967) formula is distributed to each kebeles proportionally. Using Yemane formula at 5\% level of signifance and total target population, female member household $(\mathrm{N})$, sample size $(\mathrm{n})$ was:

Table 1 : Sample size

$$
n=\frac{N}{1+N(0.0064)}=\frac{1553}{1+1553(0.0025)}=318
$$

\begin{tabular}{|l|l|l|l|l|l|}
\hline Kebeles & Female HH & Percentage of total & Sample & Percentage \\
\hline \multirow{5}{*}{ Dambi Dima } & Irrigated & 158 & 10.2 & 33 & 10.5 \\
\cline { 2 - 6 } & Non irrigated & 683 & 43.9 & 140 & 43.8 \\
\cline { 2 - 6 } & Total & 841 & & & \\
\hline \multirow{5}{*}{ Dambi Gobu } & Irrigated & 152 & 9.8 & 31 & 9.7 \\
\cline { 2 - 6 } & Non irrigated & 560 & 36.1 & 114 & 36 \\
\cline { 2 - 6 } & Total & 712 & & 318 & 100 \\
\hline \multicolumn{2}{|l|}{ Total } & 1553 & & & \\
\hline
\end{tabular}

\subsection{Data Collection Methods and Data Processing and Method of Analysis}

The study used only primary data source. The primary type of data source was collected by structured interview, after converting questionnaire to Afan Oromo. The researcher used structured interview because it's convenient to mitigate non-response. Moreover, some respondents are illiterate and cannot fill questionnaire and hence structured interview was the best method. The secondary data was used gathered from irrigation Bureau of Bako Tibe woreda that were used only in literatures.

Carefully collected primary data was inserted to Microsoft excel in such a way that it would be suitable for STATA to draw objectively consistent analysis using both descriptive and inferential analysis.

Though the main focus of the study is to answer whether irrigation increase in female labor allocation on farm activities will increases or decreases with irrigation activities or not unless all determinants of female labor time allocation on farm activities are fully incorporated coefficient of irrigation will be biased (Verbeek, 2004; Wooldridge,2002 ). Hence, Econometric model is like determinants of female labor time allocation on farm activities. Most model such kind employ binary dependent variable and are at micro level taking dependent variable as participated or not. In this study dependent variable is the number of hour that women spend on irrigation. Once, dependent variable is determined, explanatory variables are explained as follow.

1. Age of the household head (AG): It is a continuous variable, defined as the farm household female age is 
the number of years from the date of birth to the day of the survey interview date in full year. Those household heads having a higher age due to a good farm experience will have much better association with more participation, and it will be hypothesized that household heads with certain age range may have more participation.

2. Cultivated area of land $(\mathbf{C L})$ : It is a continuous variable which is the total irrigated area of land by the household. It is measured in hectares. Larger firms might benefit from economies of scale, but larger farms can also practice less intensive forms of agriculture, which will result in higher female labor force participation

3. Agricultural labor input (AL): This refers to the total number of family members of the household who have directly involved on the farm activity measured in adult. It is measured by the number of all family members who will be involved in farm activity. The more the labor force utilized for the farm production process the less female come out of home. Therefore, agricultural labor will be hypothesized to have a negative impact on female labor force

4. Educational level (EDU): The number of years or the highest grade completed by the household head during the survey period. Household heads who attend more level of education will be expected to have more exposure to the external environment and accumulate knowledge of farm practicing. They have a better ability to identify the problem of their farm income as well as analyze its costs and benefits. Therefore, it will be expected that those farmers who are advanced in school level have better opportunity for agricultural participation (Lelissa, 1998, Beyene, 2000 \& Tesfaye \& Ayenew, 2016).

5. Household size (HHS): It is a continuous variable, defined as the total number of members living together in family during the survey period. Those households having a large number of family sizes may need higher crop production and will affect positively the female labor force participation.

6. Sex of the household head (SEX): this is a dummy variable that assumes a value of "1" if the head of the household is female and " 0 " otherwise. These are related to women's lack of control over economic resources and the nature of their economic activity". With this background including the existing gender differences; female headed households will have mobility, participate in different meetings and have more exposure to participate in labor force

7. Extension service (EXTN): It is a dummy variable which measured whether the household used the extension program or not during survey period. Households those who will be used extension service during their sugarcane production process would expect to increase the probability of farm productivity.

8. Irrigation used (IR): It is also a dummy variable which measured whether the household used the irrigation system or not during the survey period. Households those who will be used irrigation for crop production process during the survey period would expect to increase the probability of farm productivity.

9. Presence of young children at home (PYC): this is a dummy variable that assumes a value of "1" if the household has young children at home that serve as home worker and " 0 " otherwise.

At the end the relationship between dependent and independent variables are going to be seen (coefficient determination) by instrumental variable. Since the objective of this research is to see the effect of irrigation on female participation, it is model of treatment.

\subsection{Model specification}

Suppose $X_{i}$ is a variable randomly selected from a population such that treatment is binary $\left(X_{i} \epsilon\{0\right.$ (control), 1(treatment) and we observe outcome variable $Y_{i}$. Moreover, let $Y_{i}(1)$ and $Y_{i}(0)$ are corresponding outcome without and with treatment variable, respectively. Having this the observed outcome will be equal to the potential outcome corresponding to the assigned treatment,

$Y_{i}=X_{i}$. let $Y_{i}(1)+\left(1-X_{i}\right) . Y_{i}(0)$

Besides, assume that a set of observed control variables $Z$ exist such that strong ignorability holds given $Z$ and the propensity score $(\pi(Z)=\operatorname{pr}(X=1 \mid Z)$ is strictly greater than zero and less than one over $Z$,

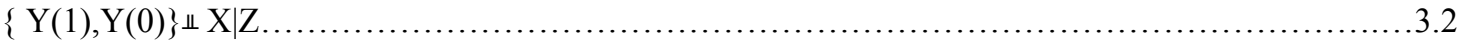

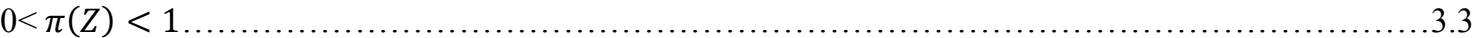

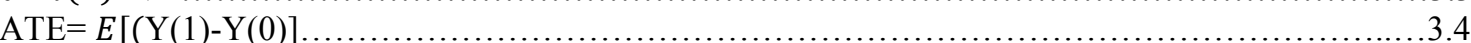

For regression model for the outcome variable $\mathrm{Y}$, the conditional expectation of $\mathrm{Y}$ given $\mathrm{X}$ and $\mathrm{Z}$ : $\mathrm{E}(\mathrm{Y} \mid \mathrm{X}, \mathrm{Z})$ is the Average treatment effect.

$\mathrm{ATE}=E[E(Y \mid X=1, Z)-E(Y \mid X=0, Z)]$

where the outer expectation is taken with respect to the distribution of $Z$. The empirical distribution of the conditioning set provides easy estimates of $\mathrm{Fz}$ and the corresponding regression estimator takes the form,

$\widehat{A T E}=\frac{1}{n} \sum_{i=1}^{n}\{E(Y \mid X=1, Z)-E(Y \mid X=0, Z)\}$

Where $E(Y \mid X=1, Z)$ the estimated conditional expectation of the outcome given $Z$ within treatment is group and $E(Y \mid X=0, Z)$ is the estimated conditional expectation of the outcome given $Z$ within control group. These conditional expectation functions can be estimated using any consistent estimator. Equation 3.6 is a model of 
regression. Treatment model deviates from this equation. If the true model for the probability of treatment assignment were known, then this could be used to define propensity scores for every unit, and these could be used for matching or weighting estimators. Because the treatment assignment model is usually unknown, matching and weighting estimators either explicitly estimate the propensity score function model or utilize the treatment assignment model implicitly through notions of balance. If the propensity score model is estimated, a well-known weighting estimator is the Inverse Probability Weight (IPW) estimator,

$\widehat{A T E}=\frac{1}{n} \sum_{i=1}^{n}\left\{\frac{X_{i} Y_{i}}{\widehat{\pi}\left(Z_{i}\right)}-\frac{\left(1-X_{i}\right) Y_{i}}{1-\widehat{\pi}\left(Z_{i}\right)}\right\}$

Where $\widehat{\pi}\left(Z_{i}\right)$ is the estimated propensity score, that is the estimated conditional probability of treatment given $Z$. If the propensity scores were known, then this estimator will be unbiased for the ATE (Tsiatis 2006). However, the simple IPW estimator is also widely believed to have poor small sample properties when the propensity score gets close to zero or one for some observations

A number of advances to the basic IPW estimator can be made. One way the IPW estimator can be improved is by fully utilizing the information in the conditioning set (Imbens 2004; Lunceford and Davidian

2004). The conditioning set $Z$ contains information about the probability of treatment, but it also contains predictive information about the outcome variable.

$A \widehat{T E}=\frac{1}{n} \sum_{i=1}^{n}\left\{\left[\frac{X_{i} Y_{i}}{\widehat{\pi}\left(Z_{i}\right)}-\frac{\left(1-X_{i}\right) Y_{i}}{1-\widehat{\pi}\left(Z_{i}\right)}\right]-\frac{\left(X_{i}-\widehat{\pi}\left(Z_{i}\right)\right)}{\widehat{\pi}\left(Z_{i}\right)\left(1-\widehat{\pi}\left(Z_{i}\right)\right)}\left[1-\widehat{\pi}\left(Z_{i}\right) E\left(Y_{i} \mid X_{i}=1, Z_{i}\right)+\right.\right.$

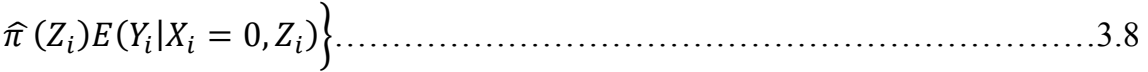

Equation 3.8 is augmented inverse probability weight (AIPW) model which is combination of basic IPW and some weighted average of the two regression estimators. It has as a number of very smart theoretical properties. This estimator is asymptotically normally distributed and valid large-sample standard errors.

Another method through which IPW could be improved is inverse probability weight regression adjustment (IPWRA) developed by Wooldridge (2010) which was basically developed for missing data.

Both AIPW estimators and inverse-probability-weighted regression-adjustment (IPWRA) estimators combine models for the outcome and treatment status; similarly both of them are virtually called double robust. While IPWRA estimators emerge naturally from a robust approach to missing-data methods, the AIPW estimator is an IPW that comprises an augmentation term that corrects the estimator when the treatment model is missspecified. IPWRA estimators use the inverse of the estimated treatment-probability weights to estimate missingdata-corrected regression coefficients that are subsequently used to compute the potential-outcome means (POM). But, both need only either outcome model or the treatment model correct specification for consistent estimate. Hence, it would be difficult to posit one is better than other because both have respective advantage.

However, there must be clear preferences among regression adjustment (RA), IPW and AIPW. RA models outcomes. That is, it simply compare mean of treated and untreated after regression. IPW models treatment probability while AIPW models both treatment and outcome probability (This study mainly rely up on AIPW though others were used just for comparison.

Assumptions Required

A. Conditional independence

Conditional independent states that there must not be dependence between the treatment model and the potential outcomes. That is, when no unobservable variable affects both potential outcomes and the treatment assignment the potential outcomes are conditionally independent of the treatment. More specifically, f we observe enough covariates, the potential outcomes may indeed be conditionally independent of the treatment. In this study equation 3.2 shall be satisfied.

\section{B. The overlap assumption}

The overlap assumption entails that each individual have a positive probability of receiving each treatment level. Formally, the overlap assumption requires that for each possible covariate in the population and each treatment level the probability shall be between zero and one (equation 3.3). It this assumption fail, we will have one more additional difference among estimation methods. Regression adjustment shows more slowly than IPW, AIPW, IPWRA the difference between treated and untreated if outcome model specified correctly.

\section{$4 \quad$ Results And Discussions}

\subsection{Descriptive Analysis}

4.1.1 Determinants of Female labor time allocation

1) Age of respondents

Age of respondents ( females) was considered in that different ranges of ages would not have equal experiences, exposure to technology, accessibility to information, level of education and so on which would affect irrigation participation decision and the time they allocate for irrigation. Though age was asked in open ended form on questionnaire, using STATA command conversion the study used in the form of range. 
Table2: Age of Respondents

\begin{tabular}{llll}
\hline Age & Frequency & Percentage & Cumulative \\
\hline $\mathbf{1 0 - 2 4}$ & 1 & 0.31 & 0.31 \\
$\mathbf{2 5 - 3 9}$ & 226 & 71.07 & 71.38 \\
$\mathbf{4 0 - 6 0}$ & 33 & 28.62 & 100 \\
Total & 318 & 100 & \\
\hline
\end{tabular}

Source: Own field survey, 2020

The above table 2 reveals ranges of age structure. Accordingly, the largest percentage of respondents lies in the range 25-39 in years where as the smallest lies in the range 10-24 in years. Respondents whose age between 25 and 39 comprises $71 \%$ and the remaining two ranges are only $29 \%$. This implies that it is possible to say that there were few youth female who was interviewed and the greatest proportion of respondents are adults. On the other hand, the average age of all respondents is 37.37 years. If we see age structure using irrigators and nonirrigators (table 8) on average non- irrigators are younger than irrigators. The average age of all irrigators is 49.36 years where as for all non-irrigators is 34.36 years. The difference between irrigators and non-irrigators in terms of age is 14.96 years which is highly significant.

The relatively older irrigators may emanate from the issues of land ownership. If we see the relationship between age and land, it reveals that older person have land (slight linear relationship in between. This is due to the fact that there was no recent land ownership reform in Ethiopia and it is straight forward that inheritance or/ and share of land of father to son/daughter is very rare.

However, it can be shown that those who do have received extension services are relatively younger than who don't receive. The average age of extension services recipients is 36 year where as for non- recipients is 39 years with age difference 14.94 on average which is highly significant. This indicates that extension service recipients (relatively younger) are proximate to technology. Besides, there is gradual positive relationship (data not shown) between age of female and household size which indicates that older female has relatively higher family size

\section{2) Sex of household head}

Another variable that was supposed to affect female labor time allocation on farm activity is whether they head household or not. As can be seen from figure 4.1, the majority of household heads where females have been interviewed were males $(72.6 \%)$ while the rest $(27.4 \%)$ were females. This finding make parallel with the fact that male are traditionally heads of households, particularly in rural areas (ILO, 2018). The all faceted direction power of households, except home food preparation, usually vests on males provided that they are capable of supporting and sustaining one or more individuals within the household. However, in the event when the male dies, becomes incapacitated or divorces, woman can assume the role although they tend to face tough challenges under such circumstances. This is because female headed households are more vulnerable to different kinds of problems than the male headed ones. Especially when husband die females search for sources of feeding and schooling children since there is no sustained sources of income in the rural area.

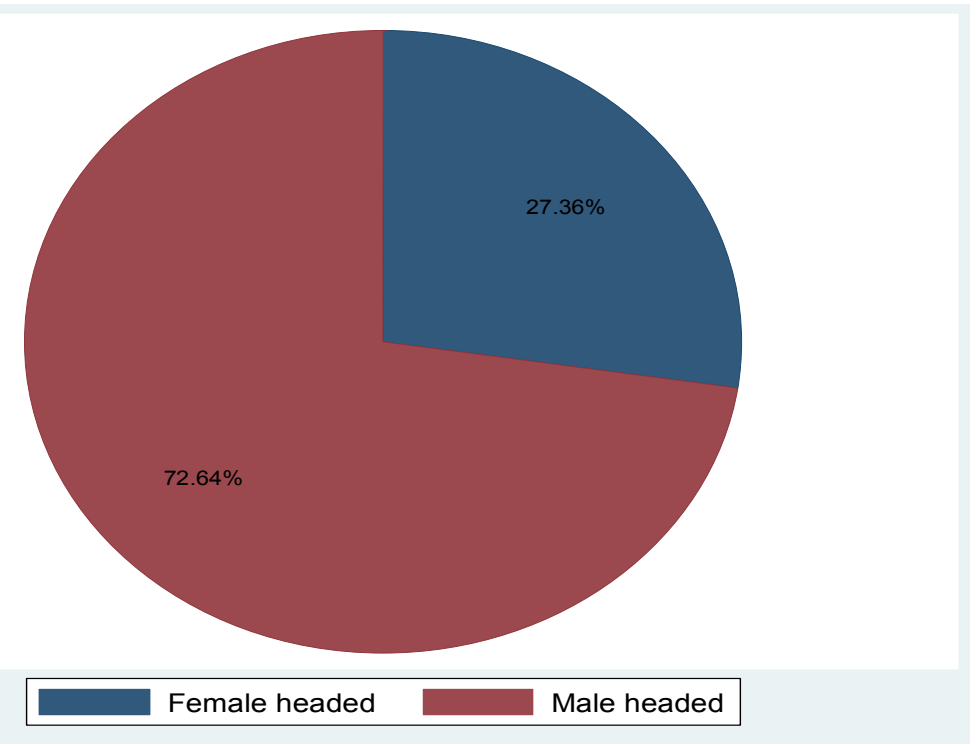

Source: Own field survey, 2020

Figure1: Female and Male headed Household

That is why, based up on sampled data, female headed irrigators spend their time ( $88.4516 \mathrm{hrs}$ per week) on farm activities more than male headed irrigators ( $80 \mathrm{hrs}$ per week) on average (Figure 2). In contrast female 
headed irrigators have average lower labor force (2.96) than male headed irrigators (3.24). This implies that female headed irrigators having lower average labor force spend relatively long farm time. However, the difference between female headed and male headed of non- irrigators on how much time they spend on farm activities is negligible and their labor force is almost equivalent (data not given). Though insignificant still female headed exceed. On average female headed household spends one hour labor time on farm activities than male headed. This is just to give bird's eye view of female labor time allocation on farm activities attributable to who heads the household.

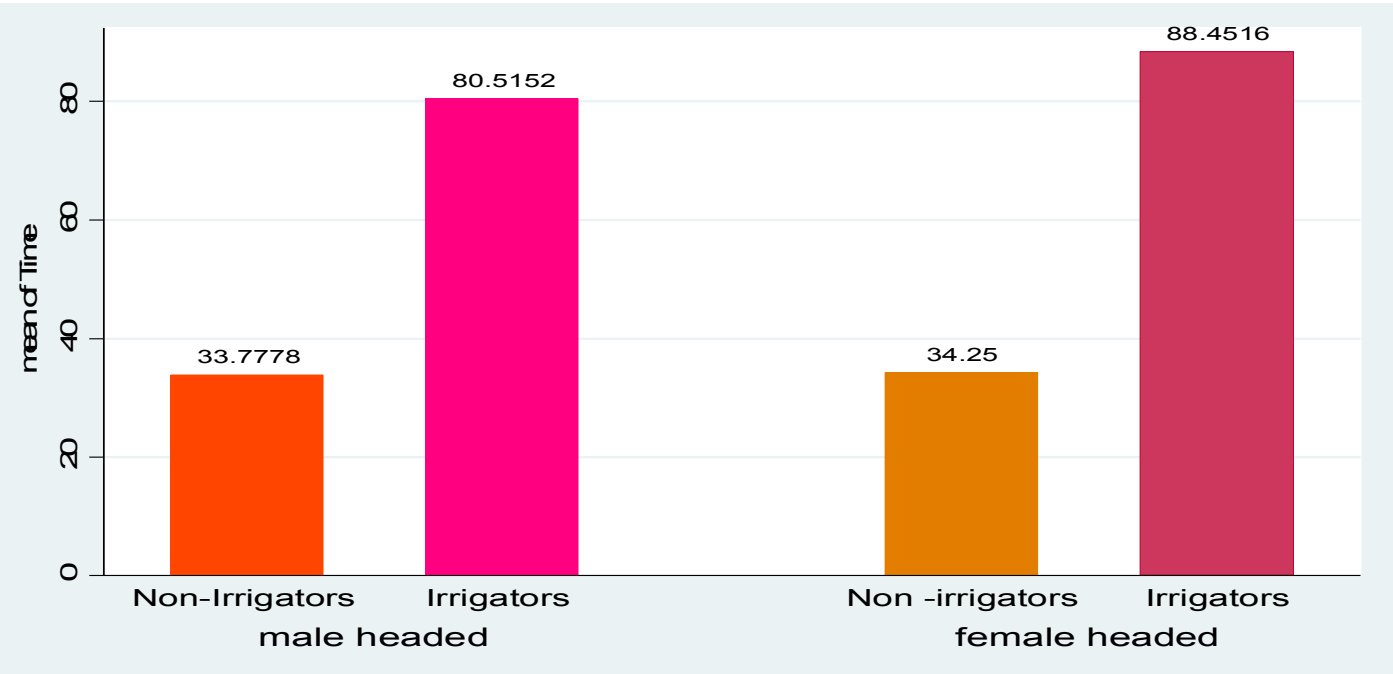

Source: Own field survey, 2020

Figure2: Mean time on household head

But, another more sound figure and pertinent to objective of the study is comparison of farm activity time of female irrigators and non- irrigators regardless of who heads households. In line to this, female irrigators (households where at least one adult female is there) spend more than double of female non- irrigators (Table 8). On average female irrigators spend $84.4 \mathrm{hrs}$ per week whereas non -irrigators spend 33.9. In fact since this time includes irrigation and non-irrigation farm activities for irrigators, the difference is very much sound. Hence, irrigators household have more farm activity time than non-irrigators household regardless of who heads it. The difference between them is 50.477 hours per week. This difference is highly significant since p value is very low. However, it does not mean the nature of household heading would not affect the time female spends on farm activities.

\section{3) Labor force}

According to CSA (2007) all persons aged ten years and over who were effectively involved or available to be engaged during the reference week are considered as economically active. This study has used definition as base reference. Accordingly, (Table 3) the largest percentage is female having two labor force appeared 111 times having $34.9 \%$ and the smallest percentage female having large labor force is labor sized 6 appeared three times having $0.94 \%$. The average labor force is 2.4 for all sample size. If we see in terms of irrigators and non-irrigators, the former has more labor force than the latter on average. The average labor force of irrigators is 3.4 whereas for non-irrigators 2.2. The mean difference of labor force between irrigators and non - irrigators is 0.88 . However, this difference is highly significant.

\begin{tabular}{llll}
\hline Labor & Frequency & Percent & Cumulative \\
\hline $\mathbf{1}$ & 64 & 20.13 & 20.13 \\
$\mathbf{2}$ & 111 & 34.91 & 55.03 \\
$\mathbf{3}$ & 103 & 32.39 & 87.42 \\
$\mathbf{4}$ & 33 & 10.38 & 97.8 \\
$\mathbf{5}$ & 4 & 1.26 & 99.06 \\
$\mathbf{6}$ & 3 & 0.94 & 100 \\
\hline Total & 318 & 100 & \\
\hline
\end{tabular}

Source: Own field survey, 2020

Though seems not plausible, but good statistical figure is comparison of labor force with standard working day. To explain let me bring average labor force of irrigators to time they allocate for farm activities and compare standard working day of Ethiopia. Since we don't know the time non-irrigators allocate for irrigation, I confine myself to irrigators alone. Irrigators have 3.4 labor forces on average which is equivalent to 136 hours per week according to standard working day ( $8 \mathrm{hr}$ per day/ per person). This time includes both irrigation and non-irrigation. 
From table 4.6 , irrigators together spend $84.4 \mathrm{hr}$ per week. The remaining 51.6 hours per week ( $40 \%$ of total time) is the amount of time from working time that females spend for home consumption if we assume that they fully utilize their time.

Table3: labor force structure of respondents

4) Household size

Table 3: household size of respondents

\begin{tabular}{llll}
\hline Size & Frequency & Percent & Cumulative \\
\hline $\mathbf{3}$ & 8 & 2.52 & 2.52 \\
$\mathbf{4}$ & 67 & 21.07 & 23.58 \\
$\mathbf{5}$ & 82 & 25.79 & 49.37 \\
$\mathbf{6}$ & 64 & 20.13 & 69.5 \\
$\mathbf{7}$ & 64 & 20.13 & 89.62 \\
$\mathbf{8}$ & 26 & 8.18 & 97.80 \\
$\mathbf{9}$ & 3 & 0.94 & 98.74 \\
\hline $\mathbf{1 0}$ & 4 & 1.26 & 100 \\
\hline
\end{tabular}

Source: Own field survey, 2020

According CSA census (2007) in West Shewa zone, the average household size in both rural and urban area was 3.6 whereas for urban area was 4.8 persons. In rural area this size was 5.0. In this study it was found to be 5.6 persons. In addition, as shown on table 4.3, the high percentage (25.79) is households having five household sizes whereas the smallest percentage (0.94) is households having 9 persons size. However, the smallest and largest percentage according to CSA (2007) was households having 1 person and 8 people respectively. If we see household size in terms of irrigators and non-irrigators, irrigators (6.45) are more populous than non-irrigators (5.49) on average. The household size between them is 0.976 which is significant

\section{5) Presence of young}

Whether young girl whose age is less than 10 years is available at home or not is also another variable that could determine the amount of time female spends on farm activities. According to figure 3 , female irrigators that has young girl at home have less farm activity time than female irrigators that have no young girl. The same is true for non-irrigators though the size of difference is different. On average, female irrigators that have no young girl spends $96 \mathrm{hrs}$ per week whereas for those with young girl is $80.79 \mathrm{hrs}$ per week. This may be due to the fact that in the rural area households virtually have no servant that care for child and it is female that is responsible for it and which prohibits them from outside activities.

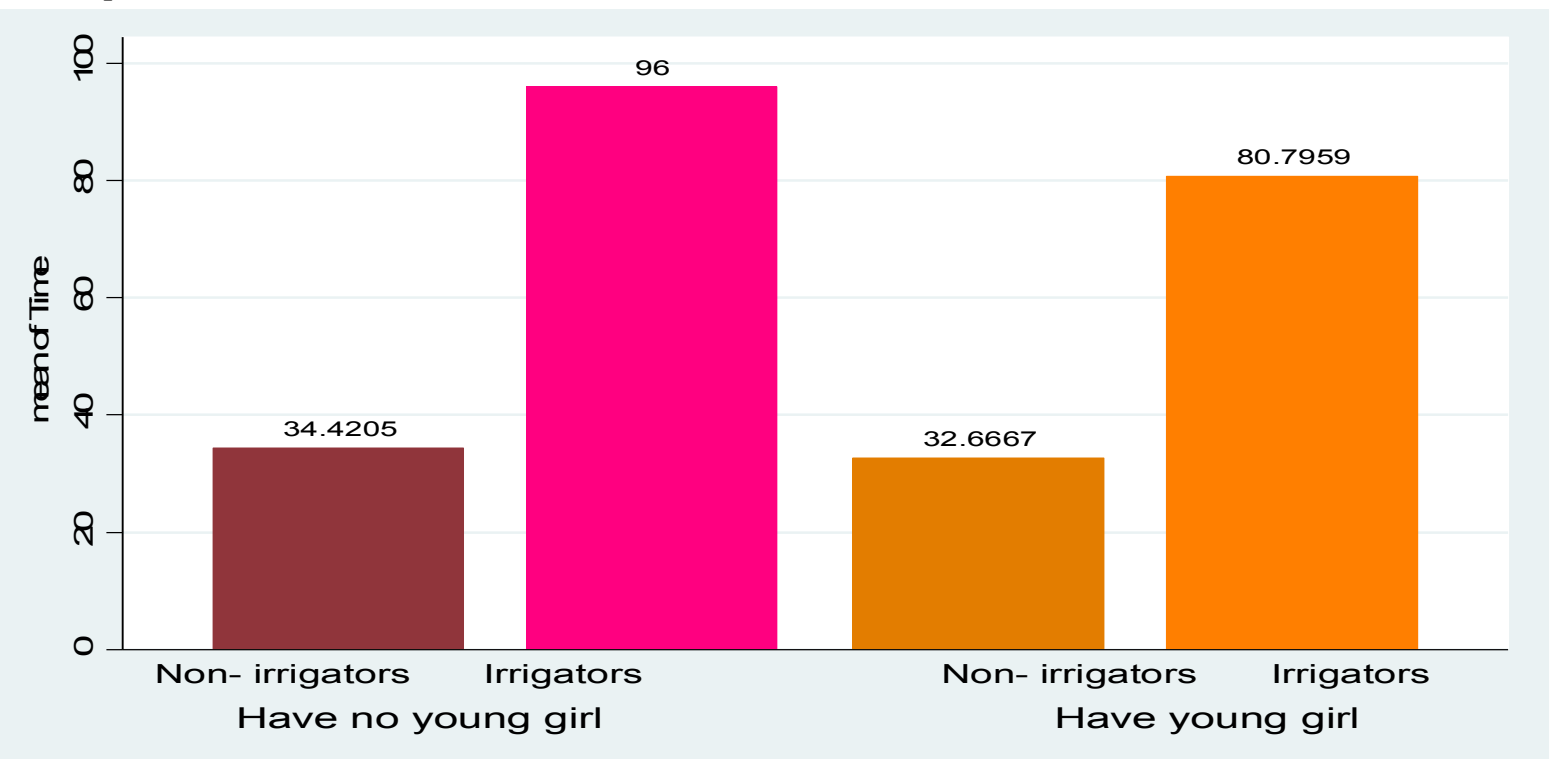

Source: Own field survey, 2020

Figure3: Mean time over existence of young girl at home 


\subsubsection{Socio-Economic Factors}

1. Education of Respondents

Table 5: Education of respondents

\begin{tabular}{llll}
\hline Education & Frequency & Percent & Cumulative \\
\hline $\mathbf{0}$ & 112 & 35.2 & 35.2 \\
$\mathbf{1}$ & 85 & 26.7 & 61.9 \\
$\mathbf{2}$ & 53 & 16.6 & 78.6 \\
$\mathbf{3}$ & 27 & 8.5 & 87.1 \\
$\mathbf{4}$ & 17 & 5.4 & 92.4 \\
$\mathbf{5}$ & 15 & 4.7 & $97 . .1$ \\
$\mathbf{6}$ & 5 & 1.6 & 98.7 \\
$\mathbf{8}$ & 4 & 1.3 & 100 \\
\hline Total & 318 & 100 & \\
\hline
\end{tabular}

Source: Own field survey, 2020

As can be seen from table 5, all respondents have at most elementary level education. The majority (35.2\%) of respondents are illiterate. Only quarter of them have one grade level education and one percent received eighth grade level. The average education level of respondents is 1.5 grades. There is also almost equal between irrigators (1.6) and non-irrigators (1.4). This difference, however, is not significant.

\section{Land size}

Total 318 respondents together operate farm activities on 385.75 hectares of land together. Of these, irrigators operate their activities on 90 hectares while the remaining non-irrigators are on 295.75 hectares. That is $20.1 \%$ of total sample size (irrigators) have owned $23.3 \%$ of total hectares of land for all respondents. The average land cultivated of total respondents is 1.2 hectares. This land township ranges from half hectare to three hectares. The majority of respondents $(24.76 \%)$ owned 1.75 hectares of lands where the minor $(0.31 \%)$ is an individual having 2.5 hectares of land.

Table 6: Cultivated land of respondents

\begin{tabular}{cccc}
\hline Land (hectares ) & Frequency & Percent & Cumulative \\
\hline $\mathbf{0 . 2 5}$ & 61 & 19.12 & 19.12 \\
$\mathbf{0 . 5}$ & 7 & 2.19 & 21.32 \\
$\mathbf{0 . 7 5}$ & 42 & 13.17 & 34.48 \\
$\mathbf{1}$ & 41 & 12.85 & 47.34 \\
$\mathbf{1 . 2 5}$ & 29 & 9.09 & 56.43 \\
$\mathbf{1 . 5}$ & 8 & 2.51 & 58.93 \\
$\mathbf{1 . 7 5}$ & 79 & 24.76 & 83.7 \\
$\mathbf{2}$ & 43 & 13.48 & 97.18 \\
$\mathbf{2 . 2 5}$ & 4 & 1.25 & 98.43 \\
$\mathbf{2 . 5}$ & 1 & 0.31 & 98.75 \\
$\mathbf{2 . 7 5}$ & 2 & 0.63 & 99.37 \\
$\mathbf{3}$ & 2 & 0.63 & 100 \\
\hline
\end{tabular}

Source: Own field survey, 2020

However, 97.18 percent of smallholders (small farms) in the area cultivate less 2 hectares of land while 47.34 percent of the farmers cultivate less than 1 hectare. In terms of irrigated and non-irrigated, on average irrigators have 1.4 hectares of land where as non- irrigators have 1.16 areas of land. This difference is significant at less than $1 \%$ (table 8).

\section{Income of respondents}

Respondents were asked how many birr they can get per month from all farm and non - farm activities. It is income from all sources. For irrigators it includes from products of irrigation and other farm activities. For non- irrigators income from selling crop and other like live stocks, chicken and others. Total respondents' together sale their products for less than half million. Mean income per month for all sample is birr 1294.31. In addition, mean income of irrigators as figure shows is birr 1757.81 whereas for non- irrigators is birr 1177.52. The difference in income for irrigators and non-irrigators is 580 which is highly significant. 


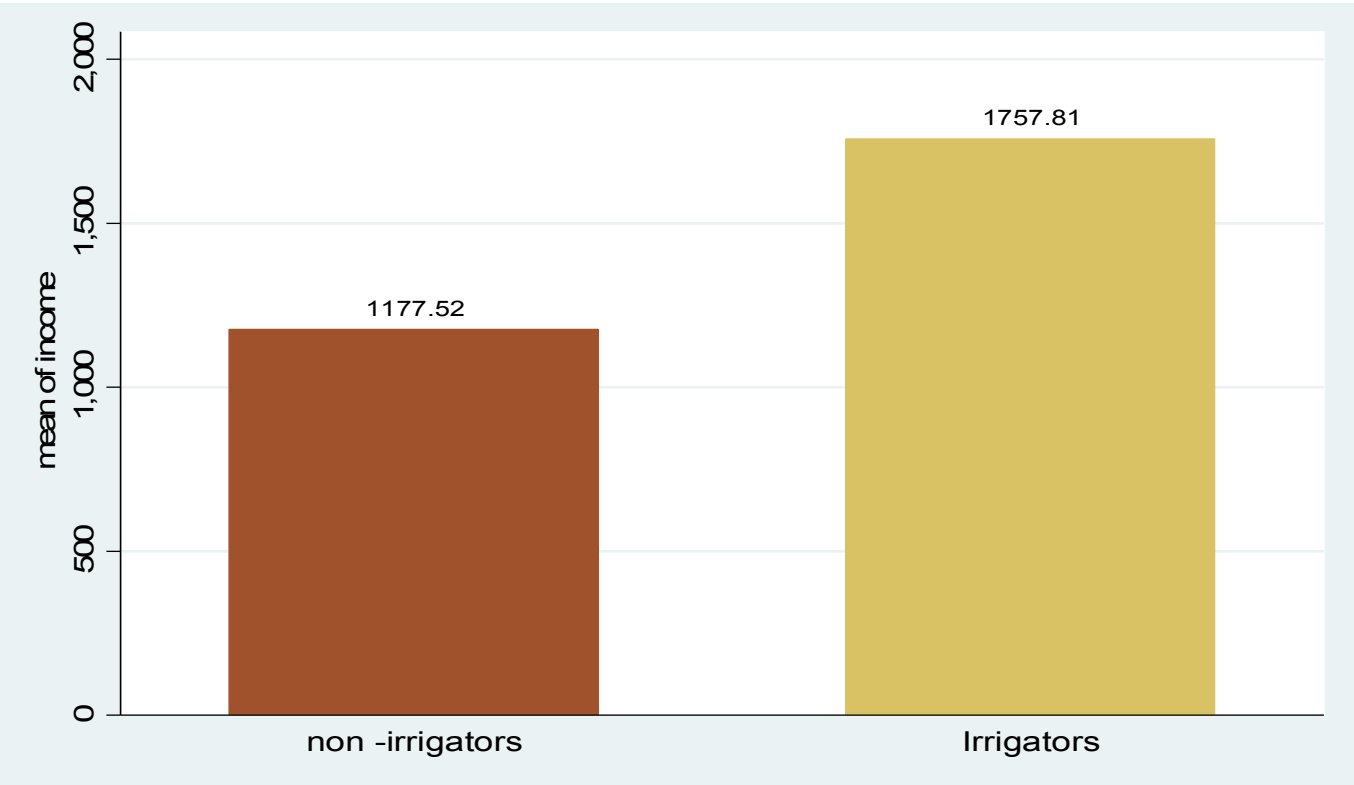

Source: Own field survey, 2020

Figure4: Mean income over irrigators and non-irrigators

4.1.3 Female Labor Time Allocation to Farm Activities and Accessibilities

A. Extension services

Another variable that could be taken while comparing irrigators and non-irrigators is extension services. By extension services we do mean farm visits by extension expert, extension meetings (experience share) visit contact model (best) farmers and class room training. Accordingly, extension service received irrigators spends a little bit more time (87.903 $\mathrm{hr}$ per week) than those who did not received irrigators (81.03). It is also visible from figure 4.5 that the time that female spends on farm activities is relatively for those did not received extension services than received between non-irrigators.

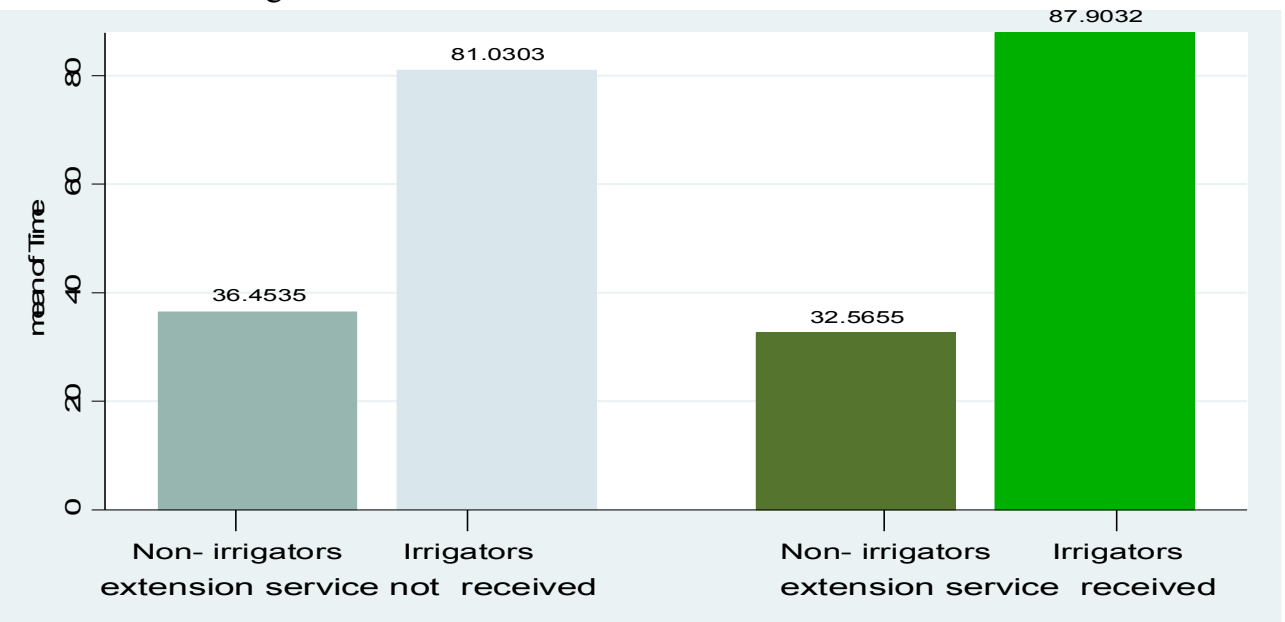

Source: Own field survey, 2020

B. Accessibility of land to Irrigation

Figure5: Mean time over extension service

The last variable that is supposed to be seen with irrigation is suitability of land for the irrigation. Sometimes river may cross land of a given farmer but, it may not be convenient for irrigation partly because it requires capital to dig out land for suitability. Oppositely in spite of suitability farmers may not engage on farm activities. In this way, according to figure 5 irrigators with accessible land have only a little bit more time than irrigators with inaccessible land. The difference cannot be greater than one hour per week. This is due to the fact that once, at initial time, inconvenient land is converted to suitable be in tradition or modern way it would not persistently affect irrigation time allocation since it is permanent. 


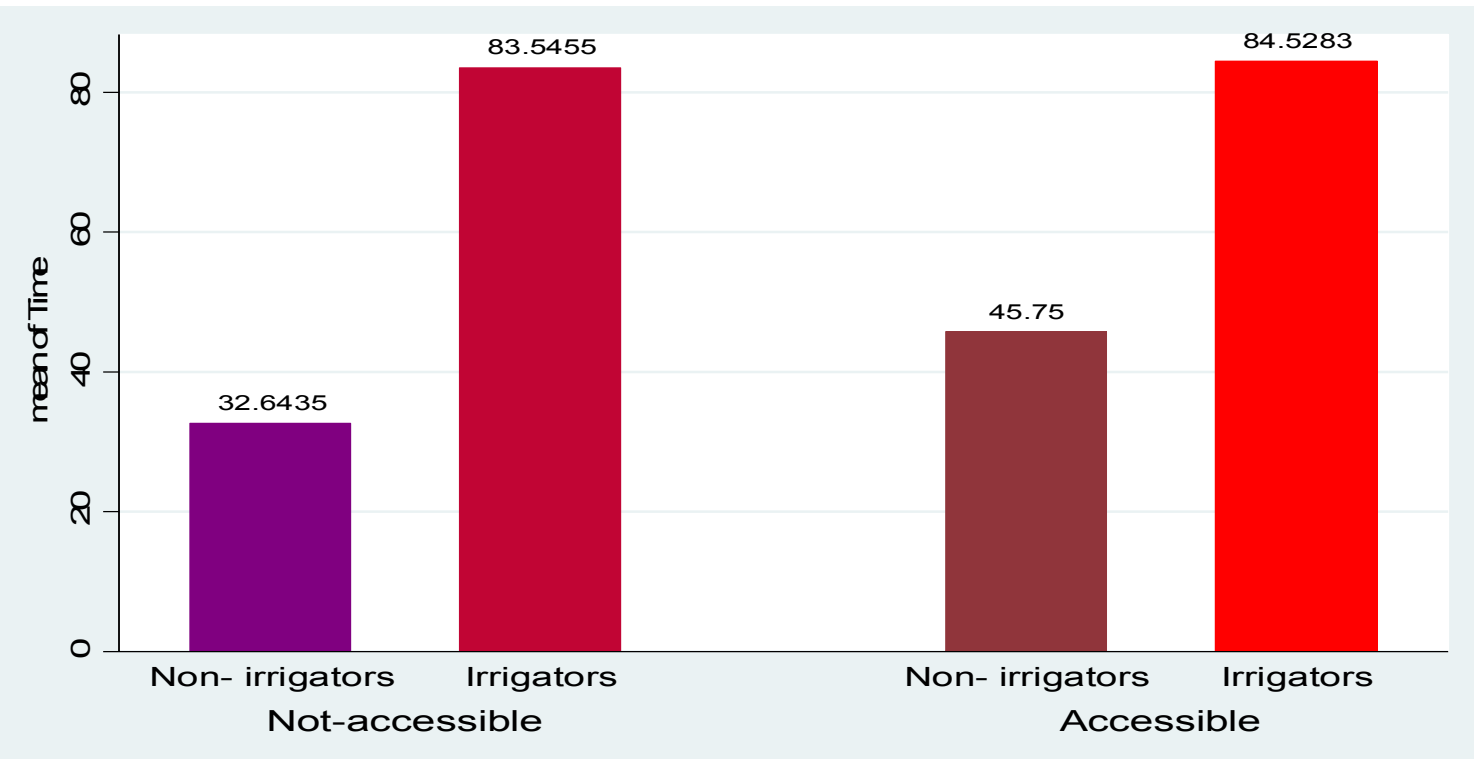

Source: Own field survey, 2020

Figur6: Mean time over accessibility of land

Table8: Comparison of irrigators and non-irrigators in continuous variable

\begin{tabular}{|c|c|c|c|c|c|c|c|c|c|}
\hline & \multirow[t]{2}{*}{ Variables } & \multicolumn{2}{|c|}{ Irrigators } & \multicolumn{2}{|c|}{ Non- irrigators } & \multirow[t]{2}{*}{$t$ test } & \multirow[t]{2}{*}{$\begin{array}{l}\mathbf{P} \\
\text { value }\end{array}$} & \multicolumn{2}{|c|}{$\begin{array}{l}\text { Both Irrigators and } \\
\text { non- Irrigators }\end{array}$} \\
\hline & & Mean & Total & Mean & Total & & & Mean & Total \\
\hline 1 & $\begin{array}{l}\text { Time allocated for } \\
\text { farm activities per } \\
\text { week }\end{array}$ & 84.3594 & 5399 & 33.8819 & 8606 & 20.36 & 0.000 & 44.04 & 14005 \\
\hline 2 & Age & 49.3 & 3157 & 34.36 & 8728 & 19.23 & 0.000 & 37.37 & 11885 \\
\hline 3 & Land & 1.4 & 90 & 1.16 & 295.75 & 2.64 & 0.009 & 1.2 & 385.75 \\
\hline 4 & Labor & 3.1 & 199 & 2.2 & 566 & 6.56 & 0.000 & 2.4 & 765 \\
\hline 5 & Education & 1.67188 & 107 & 1.45669 & 370 & 0.91 & 0.364 & 1.5 & 477 \\
\hline 6 & Size & 6.46875 & 414 & 5.49213 & 1395 & 5.06 & 0.000 & 5.688 & 1809 \\
\hline 7 & Income & 1757.81 & 11250 & 1177.52 & 299090 & 5.8 & 0.000 & 1294.31 & 411590 \\
\hline
\end{tabular}

Table 8 presents the demographic characteristics of irrigators and non-irrigators households. The mean age for irrigators female was 49.3 years and non-irrigators 34.36 years. The difference between irrigators and nonirrigators was significant at less than $1 \%$. The irrigators had larger land sizes of 1.4 ha compared to 1.16 ha nonirrigators on average. The difference in holdings was significantly different at less than $1 \%$. There was also a significant difference at less than $1 \%$ level in the number of household size and labor force between irrigators and non- irrigators. The mean labor force and household size of irrigators are 3.1 and 6.4 respectively while for nonirrigators 2.2 and 5.4 respectively. However, there is no significant difference between irrigators and non-irrigators in terms of education

\subsection{Inferential Analysis}

\subsubsection{Pre - Result discussion issues}

\section{Tests for endogeneity}

Endogeneity could arise, in this study, if unobservable factors that determine the time that females allocate for farm activities are correlated with the decision to irrigation. Equivalently it means, if there is correlation between the treatment-assignment errors and the outcome errors, there will be endogeneity. If there is no endogeneity, we would prefer to use one of the non- endogenous method estimators because they will give us the correct standard errors (Wooldridge,2010). If tests for endogeneity biases for its existence, to control for the endogeneity of treatment assignment, the estimator includes residuals from the treatment model in the models for the potential outcomes, known as a control function approach. We can also use instrumental variable if it satisfies criteria's of instrument (Wooldridge, 2010). Hence, it would better if endogeneity test is made. STATA result in treatment model will tell us whether there is endogeneity or not. Accordingly, the footer from Appendix 8 tell us that likelihood test of independence equation of errors from treatment and outcome tells us we fail to reject null 
hypothesis of no endogeneity even at $10 \%$ level of significance. However, if we exclude major significant variables (presence of young girl and accessibility) from the treatment equation endogeneity test us that there is endogeneity (Appendix 9). Based up on this result we cannot use instrumental variable method of treatment model.

\section{Heteroscedasticity}

Standard probit and logit model assumes homoscedasticity in the latent variables (Verbeek, 2004; Wooldridge, 2010). Test for heteroscedasticity in for limited dependent variables were explained by Wooldridge (2010) in section 15.5.3. If there is heteroscedasticity in the latent variable, error from the equation would be no longer independent of explanatory variables. This could be tasted using likelihood ratio test from STATA result once suspected variable correlated to error is put in appropriate command. In this study all variables are suspected and detected with heteroscedasticity. Appendix 6 shows this result. Null hypothesis of homoscedasticity is not rejected since the footer of this appendix that shows likelihood ratio test is not significant at reasonable level of significance. In fact, when heteroscedasticity robust standard error regression is carried out, education became significant. Having this in mind if one suspects error from latent is correlated to education, which may cause heteroscedasticity, allow heteroscedasticity for education and test for it, still null hypothesis is acceptable (Appendix 7). Hence, together there is no heteroscedasticity problem.

\section{Overlap assumption}

The overlap assumption is satisfied when there is a chance of seeing observations in both the control and treatment group at each combination of covariate values. On another hand, the overlap assumption is violated when an estimated density has too much mass around 0 or 1 which implies that that when the overlap assumption is violated, the estimated densities will have relatively little mass in the regions in which they overlap.

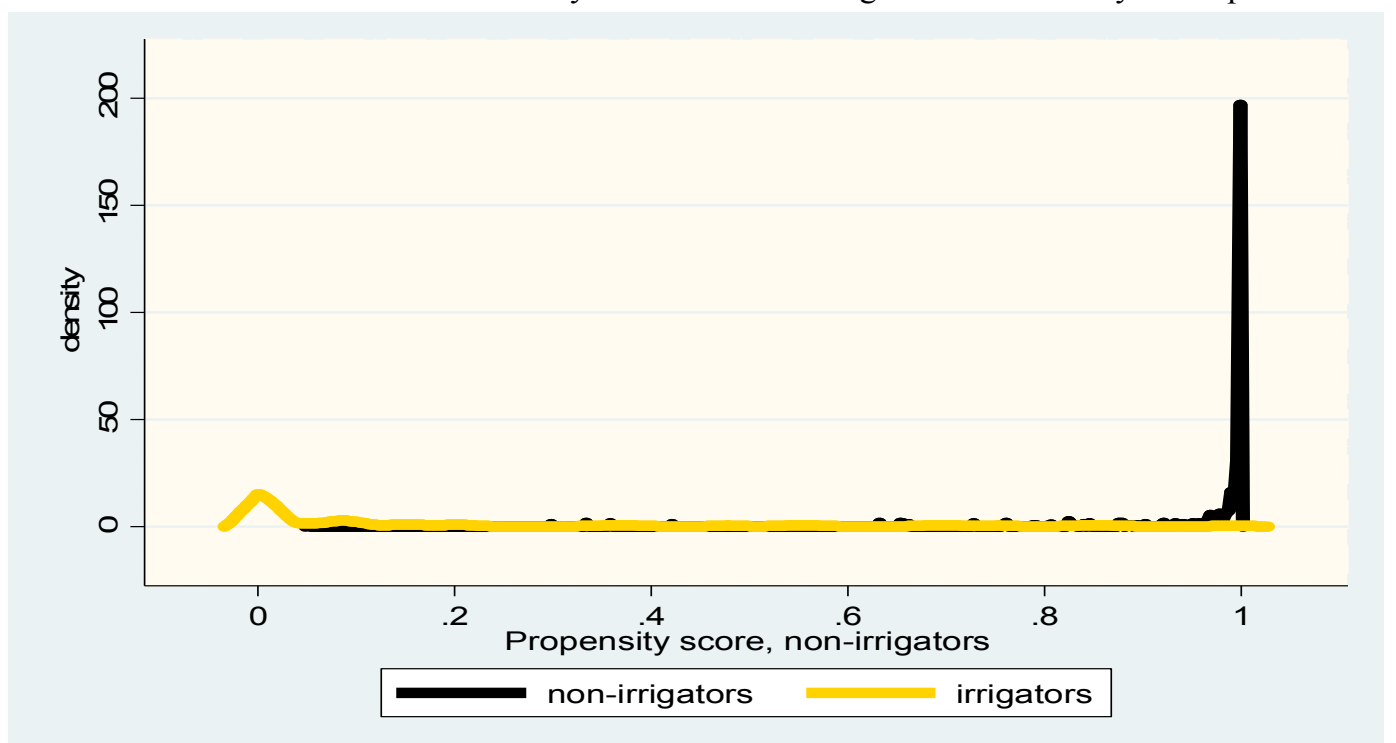

Source: Own field survey, 2020

Figure 7: overlap test

Figure 7 above shows that the estimated density of the predicted probabilities that a non- irrigators female is a non-irrigator and the estimated density of the predicted probabilities that a irrigator female is a non-irrigator.

The estimated density of the predicted probabilities that a irrigator female is a non-irrigator has most of its mass not near 0 which is an indication of non-violation. However, the estimated density of the predicted probabilities that a non- irrigators female is a non-irrigator has most of its mass near 1 which is an indication of violation of overlap assumption. However, the two have very much mass in the region in which they overlap. Hence, overlap assumption is partially violated which calls for unique form of STATA command pertinent to this. 4.2.2 The impact of Irrigation on Female labor time

We cannot estimate the impact of irrigation on time females spend on farm activities by simply taking the difference between the sample mean of irrigators and non-irrigators because there are covariates that are related to potential outcome (time) and treatment (irrigation). That is why we do have equation - outcome equation and treatment equations. If we believe there is some unobservable factor that affects both assignment to treatment and the potential outcome, there would be endogeneity (Wooldridge). That is, in this study, if there is factor that affect time that female allocate for farm activity also affects the decision of irrigation. If equation is endogenous it would be better to use instrumental variable (Wooldridge). However, we have to follow statistical test for endogeneity. This study has checked for endogeneity .

We cannot estimate the impact of irrigation on time females spend on farm activities by simply taking the difference between the sample mean of irrigators and non-irrigators because there are covariates that are related 
to potential outcome (time) and treatment (irrigation). That is why we do have outcome equation and treatment equations. Especially if the number of control and treatment sample is not balanced we cannot use regression adjustment because the difference between mean of dependent variable could be attributable to not only variable under focus but also difference in number of sample. Inverse probability solves this problem while augmented inverse probability is an improvement over inverse probability in efficiency (Wooldridge, 2010).

Table9: Impacts of Irrigation on Time in short

teffects aipw (Time age Land education sex Size ExService Presenceofyoungchild Accessibilty) (Irrigation age Land education Size sex ExService Presenceofyoungchild Accessibilty), pstolerance (1e-8)

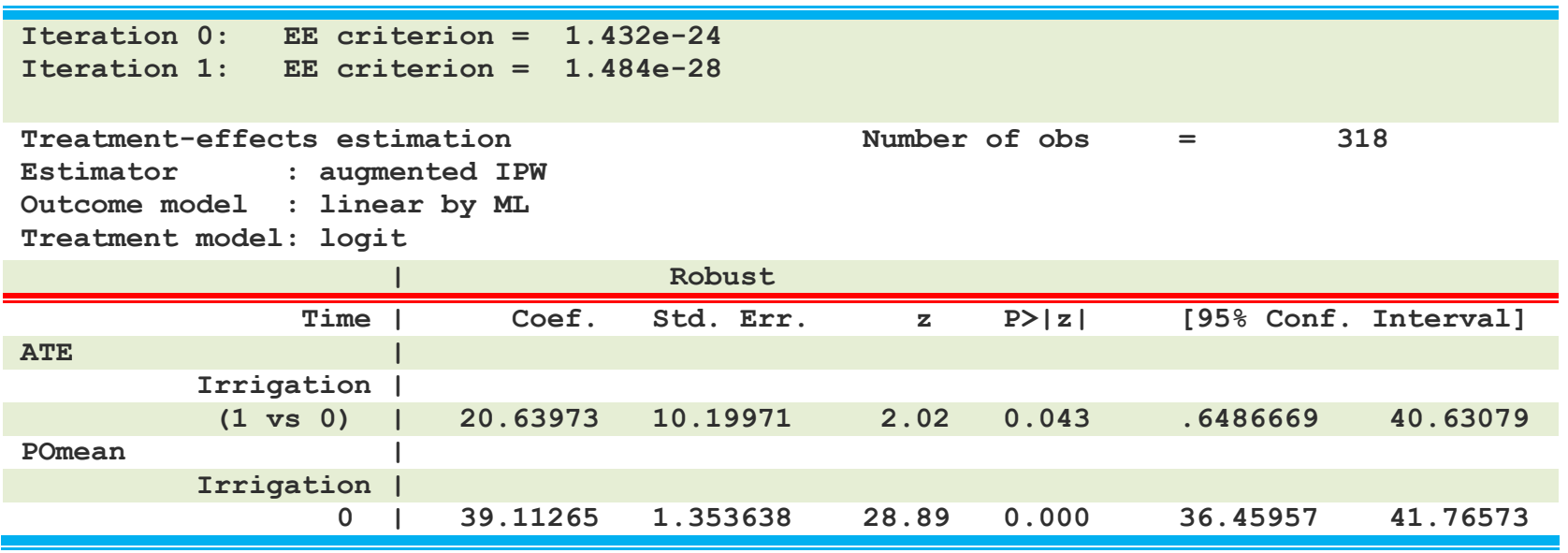

Source: Own field survey, 2020

Table 9 shows results of the impacts of irrigation on time females spend on farm activities. The treatment status has been predicted using logit model as a function of, age, land, education, sex of household head, size of household, whether household has received extension service, presence of young girl at home and accessibility of land for irrigation. The outcome variable is the amount of hour that female spends on farm activities. The outcome model has similar variables to the treatment model. In both models labor and income were excluded due to high correlation to size and land respectively.

The Augmented inverse-probability weighting model resulted that the average time that female spend on farm activities per week is 39.11 hours if none of sample size was irrigators. The average time if all females to irrigate is 20.54 hours per week more than this amount. This difference is highly significant even at less than $1 \%$ level of significance.

Table10: Impacts of Irrigation on Time in short

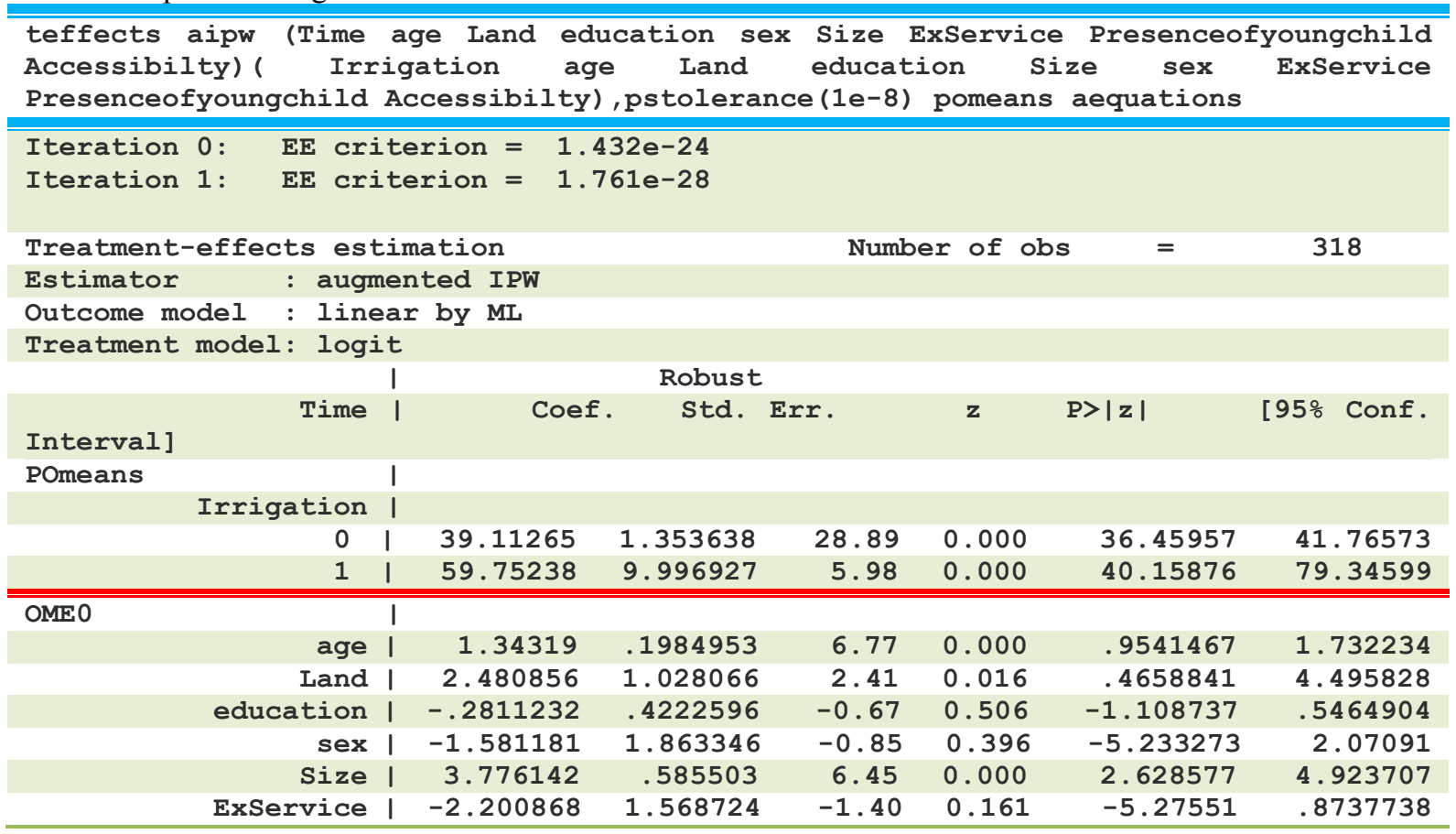




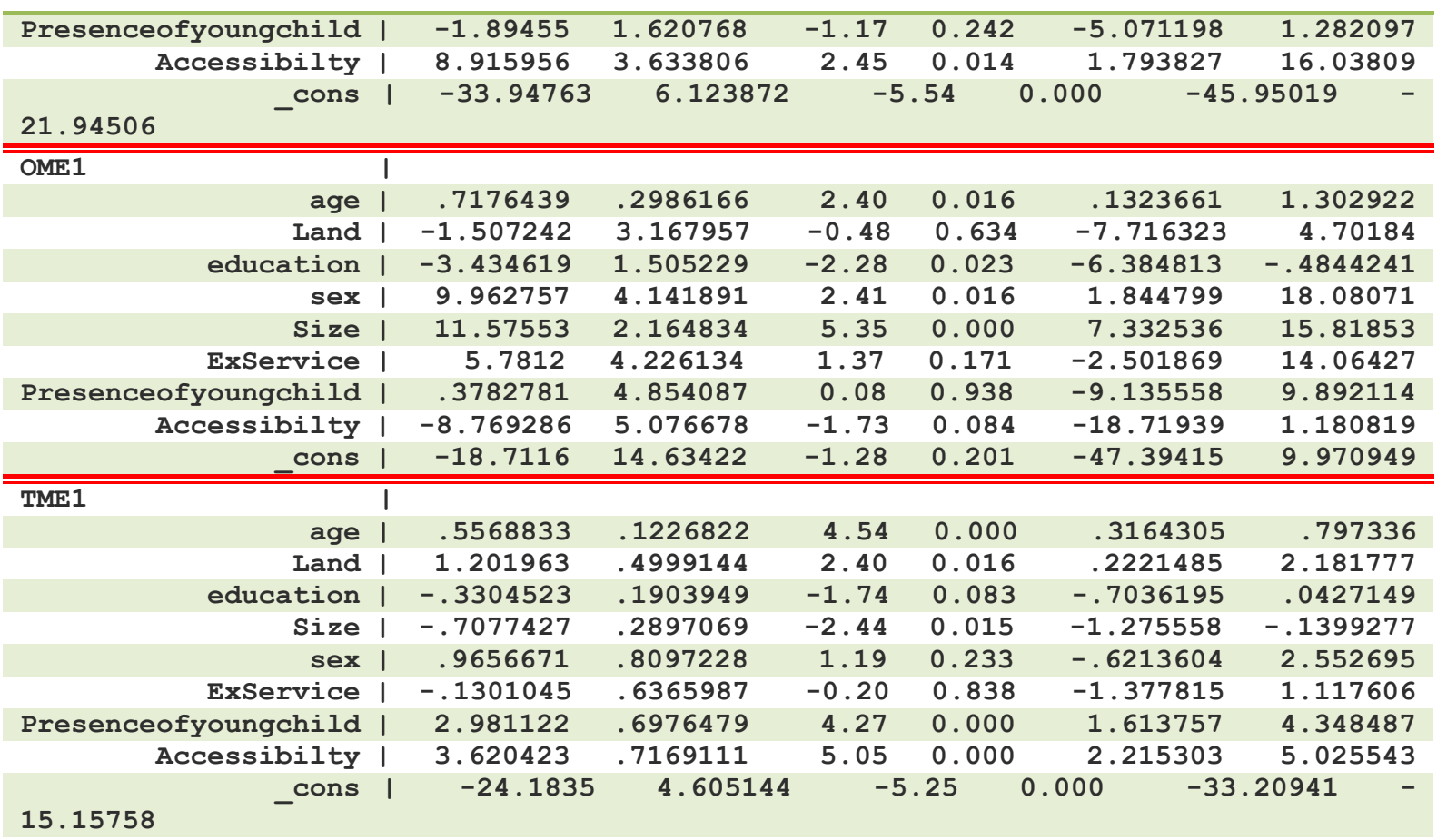

Source: Own field survey, 2020

Table 10 displays the regression model coefficients used to predict the potential outcome models as well as coefficients from the model used to predict treatment. The sections of the table labeled OME0 and OME1 represent the linear regression coefficients for the non- irrigators and irrigators potential-outcome equations, respectively. The coefficients of the TME1 equation are used in the logit model to predict treatment status.

That is if one carries out separate linear regression on irrigators alone, the result will be identical to the section OME1. Similarly, if one carries out separate linear regression on non- irrigators alone, the result will be identical to the section OME0. Regression adjustment method compares simply the difference in average dependent variable at certain covariates of these two results whereas inverse probability balances by respective inverse of probability of irrigation and non-irrigation (though not required to discuss this here).

The level of significance of different variables is different between to separate regression and combined treatment too in fact. While land, extension service and presence of young girl at home are insignificant for irrigators, education, sex of household head, extension services and presence of young girl are insignificant for non- irrigators in regressing time that female spend on farm activities of which irrigation is one. The remaining variables are respectively significant.

The section TME1 is equivalent to model of determinants of irrigation participation decision. No need of discussing the significance of each variables since has been discussed in the 4.2.1 section with only difference there probit here logit which was done deliberately just to compare the results of logit and probit as most researchers do. In fact, this is simply a tour across a road while one is on the travel with the objective of nontourism.

\section{Summary and Conclusion}

This study analyzed the impact of irrigation on female labor time of farm activities using augmented inverse probability weight method of treatment effect.

\section{Summary of descriptive result}

From total sampled population, on average non- irrigators are younger than irrigators with age difference 14.96 years which is highly significant. However, those who do have received extension services are relatively younger than who don't receive with age difference 14.94 on average which is highly significant too. This indicates that extension service recipients (relatively younger) are proximate to technology. Besides, there is gradual positive relationship between age of female and household size which indicates that older female has relatively higher family size.

The majority of household heads where females have been interviewed were males $(72.6 \%)$ while the rest (27.4\%) were females. Female headed irrigators spend their time ( $88.4516 \mathrm{hrs}$ per week) on farm activities more than male headed irrigators. In contrast female headed irrigators have average lower labor force (2.96) than male 
headed irrigators (3.24). However, the difference between female headed and male headed of non- irrigators on how much time they spend on farm activities is negligible and their labor force is almost equivalent. Regardless of whom heads household female irrigators spend more than double of female non- irrigators. On average female irrigators spend $84.4 \mathrm{hrs}$ per week whereas non -irrigators spend $33.9 \mathrm{hrs}$ per week.

The average labor force total sample is 2.4 people. If we see in terms of irrigators and non-irrigators, the former has more labor force than the latter on average though underemployed if compared to standard working day. The average labor force of irrigators is 3.4 whereas for non-irrigators 2.2. The mean difference of labor force between irrigators and non - irrigators is 0.88 . Though seems small in absolute number, this difference is highly significant. Moreover, irrigator females spend $40 \%$ of total time from working time for home consumption if we assume that they fully utilize their available time. Moreover, irrigators are more populous than non-irrigators on average. The household size between them is 0.976 which is significant.

Female irrigators that have young girl at home have less farm activity time than female irrigators that have no young girl though the probability of participation on irrigation increases with the former. The same is true for non-irrigators though the size of difference is different. On average, female irrigators that have not young girl spends $96 \mathrm{hrs}$ per week whereas for those with no young girl is $80.79 \mathrm{hrs}$ per week. Regarding to land size, $20.1 \%$ of total sample size has owned $23.3 \%$ of total hectares of land for all respondents. The average land cultivated of total respondents is 1.2 hectares. However, 97.18 percent of smallholders (small farms) in the area cultivate less 2 hectares of land while almost half of total sample (47.34 percent) cultivate less than 1 hectare. In terms of irrigated and non-irrigated, on average irrigators have 1.4 hectares of land where as non- irrigators have 1.16 areas of land.

Mean income per month for all sample is birr 1294.31 per month. In addition, mean income of irrigators is birr 1757.81 whereas for non- irrigators is birr 1177.52. The difference in income for irrigators and non-irrigators is 580 which is highly significant. Extension service received irrigators spends a little bit more time than those who did not received irrigators with accessible land have also only a little bit more time than irrigators with inaccessible land. The difference cannot be greater than one hour per week.

\section{Summary of econometric result}

Econometric result of inferential analysis used binary probit model to analyze determinants of irrigation decisions and augmented inverse probability weight of treatment effect model to see the impact of irrigation on female farm time allocation. Accordingly, of all included variables in the probit model, age, presence of young child at home, household size, land and accessibility of land to irrigation significantly affect female irrigation participation. Education of female, sex of household head and extension services are found to be insignificant even at $10 \%$ of level of significance.

A one year increase in age of female would increases $Z$ score by 0.28 . Similarly, a one year increase in age of female significantly increases the likelihood of irrigation participation by $0.96 \%$. The probability of participation in irrigation would increase by $22.4 \%$ with land accessible to river than those with no accessibility. The probability of participation in irrigation would increase by $10.4 \%$ for a female having young girl at home than female haven't young girl at home. A one hectare increase in cultivated land would increase the probability of participating on irrigation of female by $2.1 \%$. A unit increase in household size significantly decreases the likelihood of the female participation by $1.6 \%$.

The Augmented inverse-probability weighting model resulted that the average time that female spend on farm activities per week is 39.11 hours if none of sample size was irrigators. The average time if all females to irrigate is 20.54 hours per week more than this amount.

\section{Conclusions}

Descriptive analysis shows that females that have longer farm labor time are females having relatively high labor force and high family size, older; females have no young girl at home, females whose land is accessible to river, females having relatively larger area of land and females with relatively high income.

There is no significant difference between irrigators and non- irrigators of farm labor time allocation based up on education. Similarly since irrigators are on average older and not proximate to information relative to nonirrigators, there is no significant difference between irrigators and non-irrigators attributable to information from extension service.

Married young females are virtually energetic. The study reveals that land owner ship go positively with age and participation in irrigation positively with land. Hence, married young females do not carry out irrigation due to the probability of having land is low. There is difference between female headed and male headed both among irrigators and non-irrigators. However, the difference between female headed and male headed on female farm labor time is greater for irrigators than non-irrigators.

Female headed irrigators household have more farm activities time per labor force than male headed. This is because female headed irrigators having lower average labor force allocate higher labor time on farm activities than non-irrigators. Moreover, irrigators spend more farm activity time than non-irrigators. 
Econometric analysis shows that the probability of female participation in irrigation would increase with increase in age of females, with accessibility of land to irrigation, presence of young girl at home and with land size. However, it would decrease with the household size. Hence, age of female, accessibility of land for irrigation, presence of young girl at home land size of household and household size affects female irrigation participation and the time female spends on farm activities.

Irrigation has impact on female labor time allocation on farm activities. This is because it significantly increases the time females spend on farm activities. The Augmented inverse-probability weighting model resulted that the average time that female spend on farm activities per week is 39.11 hours if none of sample size was irrigators. The average time if all females to irrigate is 20.54 hours per week more than this amount.

Taken together, age of females, presence of young girl at home, labor force and household size with whom females live, the size and accessibility of land of household affect females decision on irrigation participation and then their time on farm activities. However, education of females, extension service and the nature of household head do not affect females irrigation participation and then their time on farm activities.

\section{Recommendation}

Accessibility of land to irrigation is the most significantly affecting female irrigation participation. Hence, it would be better if government or NGOs working on gender and women empowerment works on how land would be suitable for irrigation so that the number of females participate on irrigation would increase. This might be through constructing canals for small scale irrigation since there is river and land alongside and at the same time not being utilized.

Though irrigation increases the time females spend on farm activity, irrigators are old aged having land. Young females with low labor force and family size, but proximate to technology are idle resources in a situation where products of these irrigations are highly demanded and bought to the places by merchants nearby city Nekemete, towns like Gedo, Sire and even Gimbi. However, there are public lands proximate to river but not being utilized. Hence, it would be better if this land is temporarily given for them for irrigation purpose.

Though sampled population is proximate to Bako town and hence irrigators are very much accessible to information about market and input utilization there is no full coverage of extension services. In fact, there might be full coverage of extension service on rain based farming. Therefore, it would be better if government increases the service coverage by extension workers working on irrigation.

\section{References}

Abraham G., Addis A., Mesfin T. (2015). The Impact of Small - Scale Irrigation on Income of Rural Farm Ho useholds: Evidence from Ahferom Woreda in Tigray, Ethiopia. Vol. 4, No. 4, 2015

Alesina, A., Giuliano, P., \& Nunn, N. (2013). On the origins of gender roles: Women and the plough. The Quarterly Journal of Economics, 128(2), 469-530.

ARDO (2018). Annual Report of Agricultural and Rural development office, unpublished, Bako Tibe Woreda

Aregu, L., Puskur, R. and Bishop-Sambrook, C. 2011. The role of gender in crop value chain in Ethiopia. Paper presented at the Gender and Market Oriented Agriculture (AgriGender 2011) Workshop, Addis Ababa, Ethiopia,

Bekele Y., Nata T., Bheemalingswara K. (2012). Preliminary Study on the Impact of Water Quality and Irrigation Practices on Soil Salinity and Crop Production, Gergera Watershed, Atsbi-Wonberta, Tigray,Northern Ethiopia, MEJS. 4(1): 29-46.

Bunclark, L. (2010). Rainwater harvesting: A suitable poverty reduction strategy for small-scale farmers in developing countries? A dissertation submitted to the School of InternationalDevelopment of the University of East Anglia in part-fulfilment of the requirements for the Degree of Master of Arts November 2010.

Cazes, S., and S. Verick .( 2013). The Labour Markets of Emerging Economies: Has Growth Translated into More and Better Jobs? Geneva and Basingstoke, UK: ILO and Palgrave Macmillan

Central Statistical Agency. (2011). Report on Livestock and Livestock Characteristics. Agricultural Sample Survey Volume II. Addis Ababa, Ethiopia

Central Statistical Agency. (2007). Population and Housing census, Addis Ababa

Central Statistical Agency. (2013). National Labour Force Survey. Addis Ababa, Ethiopia

Chilot Yirga (2012). Effect of small-scale irrigation on the income of rural farm household: the case of Laelay Maichew district, central Tigray Ethiopia

Congress of the United States (2018). Factors affecting labor force participation, Congressional Budget Office report: 2018

Ethiopian Development Research Institute and International Food Research Institute . (2012). Gender differences in access to extension services and agricultural productivity; Ethiopian Strategy Support Program II. Addis Ababa, Ethiopia

Fernández, R. (2013). Cultural change as learning: The evolution of female labor force participation over a century. 
The American Economic Review, 103(1), 472-500.

Food and Agricultural Organization of United Nations (2015). Gender equality in food security governance and agriculture: Reducing gender inequalities for increased food and nutrition security.

Food and Agricultural Organization of United Nations. (2015). Gender and Land statistics: Recent developments in FAO's gender and land rights database.

Food and Agricultural Organization of United Nations (2019). National gender profile of agriculture and rural livelihoods, Addis Ababa, Ethiopia

Gaddis, I., and S. Klasen. (2015). Economic development, structural change, and women's labor force participation: A reexamination of the feminization U hypothesis. Journal of Population Economics.27:3 (2014): 639-681.

Goldin, C. (1995). The U-Shaped female labor force function in economic development and economic history. In: Schultz, T. P. (ed.). Investment in Women's Human Capital and Economic Development.Chicago, IL: University of Chicago Press

ILO Bureau of Statistics. (2018). ILO Database on Labour Statistics, International Labour Organization.

Imbens, G. (2004),Nonparametric estimation of average treatment effects under exogeneity: A review. The

Review of Economics and Statistics 86:4-29

Imbens, G., and Angrist G. (1994), Identification and Estimation of Local Average Treatment Effects, Econometrica 62, 467-476.

Kaleab Baye and others (2019). The impacts of irrigation and women diet, IFPRI discussion paper 01864, environment and production technology division, Addis Ababa, Ethiopia

Klasen S. (2017). What explains uneven Female Labor Force Participation Levels and Trends in Developing Countries?, University of Göttingen, October 2, 2017.

kothari R. (1990).Research Methodology : methods and techniques, new age international (p) limited, publishers, New Delhi

International Labour Organisation ( 2013). Decent work country profile: Ethiopia.

MacDonald, Heather and Alan Peters (2018). Distance and labor force participation: Implication for urban and rural women; University of Iowa.

Lunceford J. and Davidian ( 2004). Stratification and weighting via the propensity score inestimation of causal treatment effects: A comparative study. Statistics in Medicine 23:2937-60

Makombe G, Namara R, Hagos F, Awulachew SB, Ayana M, Bossio D. (2011). A comparative analysis of the technical efficiency of rain-fed and smallholder irrigation in Ethiopia. Colombo, Sri Lanka: International Water Management Institute.

Martey E., Asante O., Al-Hassan R., Dogbe , C. (2013). Factors influencing participation in rice development projects. The case of small holder rice farmers in northern Ghana. International Journal of Development and Economic Sustainability

Mogues.T., Cohen .M. J., Birner.R., Lemma.M., Randriamamonjy.J., Tadesse. F., and Paulos.Z. (2009). Agricultural Extension in Ethiopia through a Gender and Governance Lens; Ethiopia Strategy Support Program 2 (ESSP2). Discussion Paper No. ESSP 007.

MOA-NRMD. Small Scale Irrigation Capacity Building Strategy for Ethiopia. Addis Ababa.

MoA. (2011a). Natural Resources Management Directorates. Small-Scale Irrigation Situation Analysis and Capacity Needs Assessment, Addis Ababa, Ethiopia.

MoA. (2011b). Natural Resources Sector, Small-Scale Irrigation Capacity Building Strategy for Ethiopia, Addis Ababa, Ethiopia.

MoWR. (2002). Water Sector Development Programme 2002-2016.IrrigationDevelopment Program, Main report. MoWR, Addis Ababa, Ethiopia

Sorsa P. ,Mares J.,Didier M.,and Rabate M. ( 2015). Determinants of the low female labour force participation in India economics department working papers no. 1207

Tasseven O., Altas D. and Targut U. (2016). The determinants of female labor force participation in OECD countries, Internal Journal of Economic Studies, Volume 2, Issue 2, Turkey

Tsegazeab G. and Surajit G. (2016). The Impact of Small Scale Irrigation on Household Income in Bambasi Woreda, Benishangul-Gumuz Region, Ethiopia

UNDP ( 2018). Ethiopia National Human Development Report 2018; Industrialization with a Human Face

Verbeek M. (2004). A Guide to Modern Econometrics. New York: John Wiley and Sons, Ltd

World Bank. 2010. Gender and Governance in Rural Services: Insights from India, Ghana and Ethiopia. Washington, DC.

Wooldridge J. M. (2002). Econometric Analysis of cross section and Panel Data. The MIT press, London

Wooldridge J. M. (2010). Econometric Analysis of cross section and Panel Data. The MIT press, London 